\title{
Characterisation of Mineralised Material from the Loki's Castle Hydrothermal Vent on the Mohn's Ridge
}

\author{
Ben Snook ${ }^{1, *}$, Kristian Drivenes ${ }^{1}$, Gavyn K. Rollinson ${ }^{2}$ and Kurt Aasly ${ }^{1}$ \\ 1 Department of Geoscience and Petroleum, Norwegian University of Science and Technology, \\ 7491 Trondheim, Norway; kristian.drivenes@ntnu.no (K.D.); kurt.aasly@ntnu.no (K.A.) \\ 2 Camborne School of Mines, University of Exeter, Cornwall Campus, Penryn, Cornwall TR10 9FE, UK; \\ g.k.rollinson@exeter.ac.uk \\ * Correspondence: ben.snook@ntnu.no
}

Received: 16 October 2018; Accepted: 5 December 2018; Published: 7 December 2018

\begin{abstract}
Loki's Castle on the Arctic Mid-Ocean Ridge (AMOR) is an area of possible seafloor massive sulphide (SMS)-style mineralisation under Norwegian jurisdiction, which, due to mounting social pressure, may be a strategic future source of base and precious metals. The purpose of this study is to characterise mineralised material from a hydrothermal vent system on the AMOR in detail for the first time, and to discuss the suitability of methods used; reflected light microscopy, X-ray diffraction (XRD), whole rock geochemistry, electron probe micro-analysis (EPMA), and QEMSCAN. The primary sulphide phases, identifiable by microscopy, are pyrite and marcasite with minor pyrrhotite and galena, but multiple samples from the Loki's Castle contain economically interesting quantities of copper (hosted in isocubanite and chalcopyrite) and zinc (hosted in sphalerite), as well as silver and gold. This reinforces the notion that slow spreading ridges may host significant base metal deposits. Micro-textures (chalcopyrite inclusions and exsolutions in sphalerite and isocubanite respectively) are typically undefinable by QEMSCAN, and require quantitative measurement by EPMA. QEMSCAN can be used to efficiently generate average grain size and mineral association data, as well as composition data, and is likely to be a powerful tool in assessing the effectiveness of SMS mineral processing.
\end{abstract}

Keywords: Seafloor sulphides; Norway; Arctic Mid Ocean Ridge; copper; zinc; mineralogy; ICP-ES/ MS; XRD; EPMA; QEMSCAN

\section{Introduction}

Socio-economic advances in developing countries have led to an increased per capita demand for a variety of mineral and metal types necessary for upgrading infrastructure, technology, and sustainable energy production [1,2]. Currently these minerals have land-based sources, but increased consumption ultimately requires an expansion and diversification of the reserves that society currently utilises. Recent deep sea research has identified a potential new source for a variety of critical metals, including copper, zinc, silver, and gold, from seafloor massive sulphides (SMS) [3-5]. These SMS deposits are present on the seafloor as active or inactive hydrothermal vent systems, and they may represent contemporary analogues of volcanogenic massive sulphide (VMS) deposits, a classic and long utilised source of base and precious metals [6].

The majority of previous SMS studies have tended to focus on deposit reviews and site discovery [3-5,7,8], deposit structure [9], general geochemistry [10], and water chemistry [11] trends. The purpose of this study is to, for the first time, perform a dedicated mineralogical study and to discuss the methods of characterisation for mineralised material from a recently discovered sulphide-bearing hydrothermal vent on the Arctic Mid-Ocean Ridge (AMOR). This has been done 
variably for other SMS localities such as the Mid Atlantic Ridge (MAR) [12-14], the Juan de Fuca ridge $[15,16]$, and others [17-19], but not for the AMOR.

One site that shows potential for SMS-style mineralisation is the Loki's Castle $\left(73^{\circ} 30^{\prime} \mathrm{N}, 8^{\circ} \mathrm{E}\right)$, located on the ultraslow spreading (6-15 mm/year [20]) AMOR, and discovered in 2008 [8]. The Loki's Castle is a site of active hydrothermal venting occurring just south of the junction between the Mohns and Knipovich Ridges, at $2400 \mathrm{~m}$ depth (Figure 1). It consists of two mounds, each approximately $150 \mathrm{~m}$ across and $30 \mathrm{~m}$ high, capped by five $10-15 \mathrm{~m}$ high black smoker chimneys releasing $310-320^{\circ} \mathrm{C}$, $\mathrm{pH} 5.5$ fluids into an ambient water temperature of $-0.7^{\circ} \mathrm{C}$ [8] (Figure 2). The site occurs on an axial volcanic ridge (AVR) rising about $1300 \mathrm{~m}$ above the adjacent valley floor and striking NE-SW for approximately $30 \mathrm{~km}$. The ridgeline displays a $50-100 \mathrm{~m}$ deep rift formed by steeply dipping normal faults, with two semi-parallel $30^{\circ}$ SE-dipping normal faults defining the NW margin of the AVR. This area is surrounded by flat-topped volcanoes and core complexes, with ridged and hummocky terrain dominated by young basaltic pillow flows, classified as tholeiitic [21]. The core complexes display strongly rotated breakaway ridges and downcurved detachment surfaces, which expose lower crustal and upper mantle lithologies. An area of increased topography to the NW of Loki's Castle is extensively normally faulted, and may represent a developing or failed core complex [22]. The importance of long lived detachment faults for hydrothermal activity at slow spreading ridges has been stated previously [8,23-25]; the normal faults which define the margin of the AVR and form the deep rifting along the AVR crest likely act as fluid pathways, therefore controlling venting occurrences [22]. A more regional setting of this section of the AMOR has been developed as a case study [26].

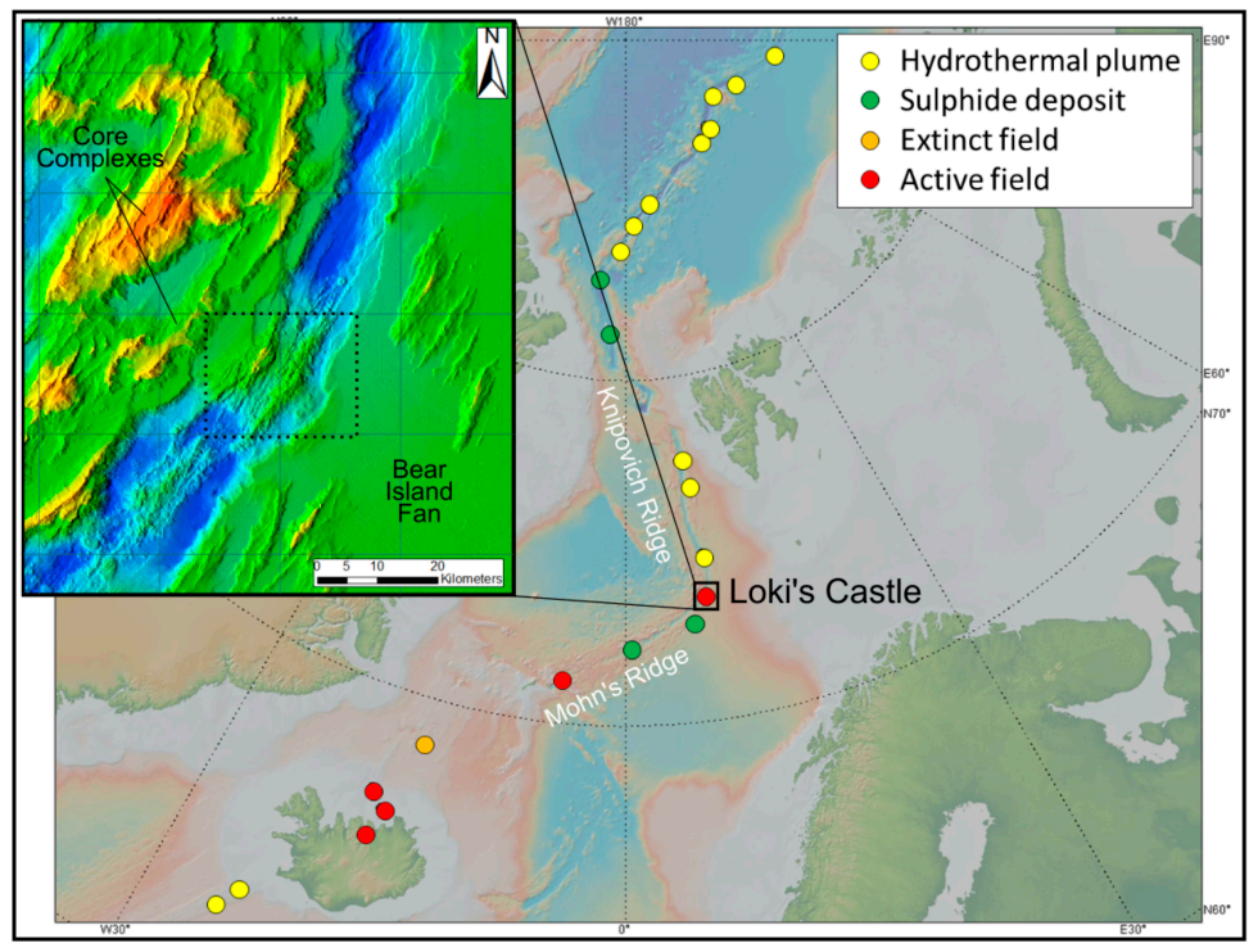

Figure 1. Location of the Loki's Castle vent, with reference to other discoveries, after data from $[8,27,28]$. Localised bathymetric inset after data from [29], indicating regional NE-SW striking structures, the Bear Island Fan to the SE and core complexes to the NW, with the area of Figure 2 demarcated. 

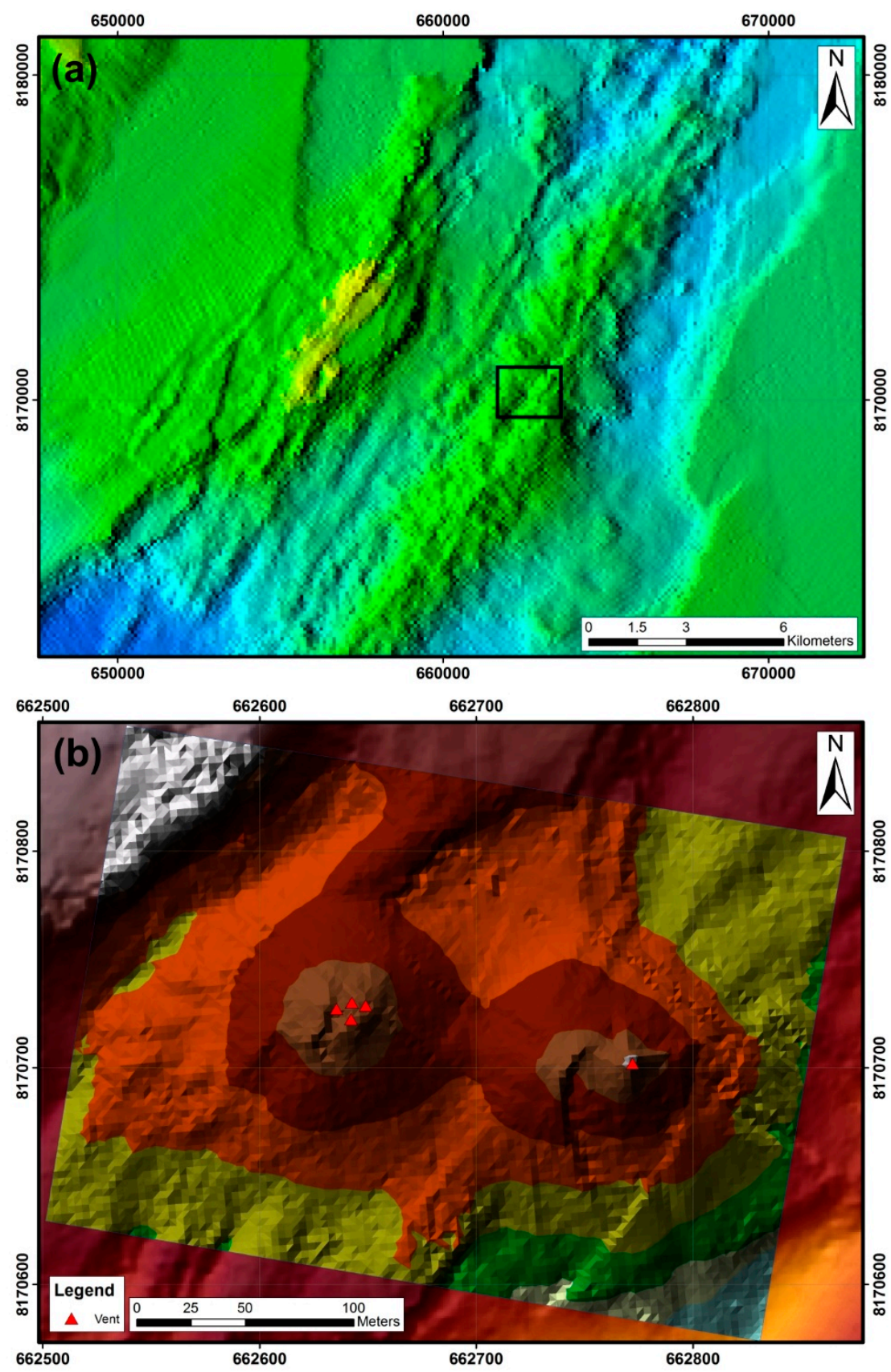

Figure 2. Bathymetry of the Loki's Castle vent system indicating (a) the axial volcanic ridge (AVR) and ridge rift, adjacent dome structure, and inset of (b) mound topography. Bathymetric after data from [29].

Due to internal fluid pressures building up and breaking pieces off, mineral phases dissolving due to changing fluid conditions, earthquakes destroying the structures completely, or the smokers simply growing too large to support their own weight, the hydrothermal vent chimneys are prone to periodic collapse. These fragments of the vent material fall down the sides of the mounds, forming scree slopes and debris fields. Although marine sediment cover on the flanks of the AVR is thinly established, the distal margins of the Bear Island Fan occur to the SE, with similar sediment accumulations in surrounding structurally controlled half-grabens [22]. This suggests that the AVR developed prior to the Bear Fan sediments reaching the site, which occurred at approximately 1.4 Ma [30]. These sediments display a rare earth element (REE) signature similar to the North American Shale Composite [21]. 
Smoker fluids are rich in non-aqueous volatiles, particularly in $\mathrm{NH}_{4}{ }^{+}, \mathrm{H}_{2}, \mathrm{CH}_{4}, \mathrm{CO}_{2}$, and $\mathrm{C}_{2+}$, with low $\mathrm{Fe}+\mathrm{Mn}$ and $\delta^{13} \mathrm{C}$ in $\mathrm{CO}_{2}$ and $\mathrm{CH}_{4}[8,31]$, which could imply ultramafic or sedimentary interactions [32,33]. Based on fluid chemistry, water-rock interactions probably occurred at a depth of approximately $2 \mathrm{~km}$ beneath the seafloor [8]. This is a typical depth [34], but the relatively thin (approximately 4 rather than $6 \mathrm{~km}$ ) crust at the AMOR [35] means that a greater proportion of this crust is cooled convectively by hydrothermal circulation.

Typical mineralogy of SMS deposits includes $\mathrm{Cu}-\mathrm{Fe}$-sulphide phases (chalcopyrite and "iss" intermediate solid solution), sphalerite, galena, and abundant pyrite and pyrrhotite $[8,13,16,18,36]$, though pyrrhotite is absent at the Trans-Atlantic Geotraverse (TAG). These authors typically report the dominant sulphate phase in SMS deposits as anhydrite, with amorphous silica and quartz as additional gangue phases.

\section{Materials and Methods}

In 2016, an extensive investigation of the Loki's Castle site was performed during the MarMine cruise [29]. Cruise goals included the collection of mineralised material for rock mass characterisation, mineral processing development, and preliminary resource modelling. In total, more than $200 \mathrm{~kg}$ of loose probable-chimney fragments from the mound flanks were recovered as non-in-situ surface grab samples by a video-guided remotely operated vehicle (ROV)-mounted hydraulic manipulator. Due to often elevated levels of sulphide-derived Fe in the vent material and general dirt and debris, the internal features of the rocks were often masked, so that remote sampling could not always guarantee the most sulphide rich material necessary for characterisation of sulphide mineralisation. However, sample collection was guided by rusty exteriors and channel/conduit structures implicit of chimneys (Figure 3). Once successfully recovered to deck, samples were vacuum-packed in double nitrogen-flushed plastic and stored at $-21^{\circ} \mathrm{C}$, in order to prevent oxidation of the sulphides. Based on visual appraisal and handheld XRF analyses, fifteen $10 \mathrm{~kg}$ blocks were determined to be of interest for sulphide characterisation.
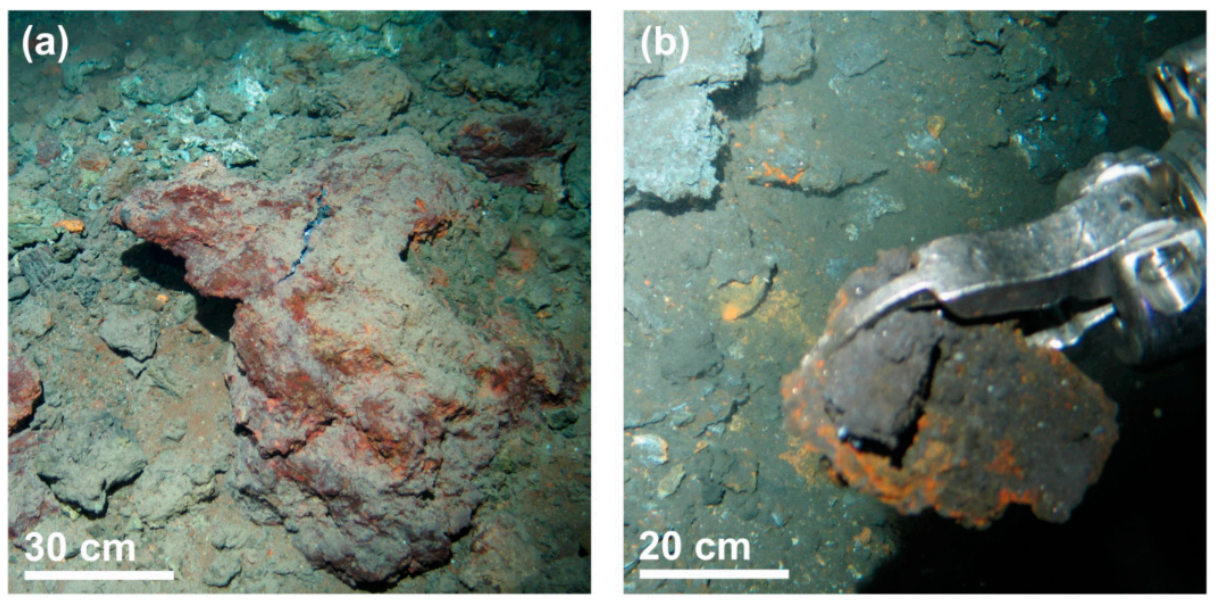

Figure 3. Example grab samples of suspected hydrothermal vent material, with (a) possible conduit structures implying fluid channels and (b) rust implying Fe derived from sulphides.

The 15 selected blocks were split down to $5-10 \mathrm{~cm}$ pieces with a diamond saw. Half of the material was re-vacuum-packed in nitrogen-flushed plastic, and stored at $-21^{\circ} \mathrm{C}$, whilst the other half was jaw-crushed to $1 \mathrm{~cm}$, riffled and half-retained, and ground in tungsten carbide planetary mills to approximately $100 \mu \mathrm{m}$ for whole-rock geochemistry. A total of $200 \mathrm{~g}$ of powder was obtained for each sample, with more produced from the larger blocks for the subsequent generation of duplicate samples to test $\mathrm{QA} / \mathrm{QC}$. 
Transmitted and reflected light microscopy and X-ray diffraction (XRD) were performed to determine major and minor mineralogy. Fifteen polished thin sections and three polished blocks were cut from the same samples selected for geochemical analyses. Semi-quantitative XRD was performed on splits from the generated sample powders (after some additional hand milling with a silica pestle and mortar) to corroborate mineralogical observations from petrography and from the literature, using a Bruker D8 Advanced XRD (Bruker, Billerica, MA, USA) with a copper tube with wavelength $1.54056 \AA$, taking measurements between $3-65^{\circ} 2 \theta$ at a stepsize of $0.01^{\circ} 2 \theta \mathrm{s}^{-1}$. Interpretation required the software diffract.Eva to identify mineral phases, and topas for quantification.

A polished block of SMS material was analysed using a QEMSCAN 4300 system with a Zeiss EVO 50 scanning electron microscope (SEM) (ZEISS, Thornwood, NY, USA) using the Fieldscan measurement mode (e.g., [37-39]). This automated mineralogy system provides detailed quantitative information and statistically robust data on textures, mineralogy, grain size, and mineral associations. A scan was performed on a carbon-coated ( $25 \mathrm{~nm}$ thickness) $30 \times 20 \mathrm{~mm}$ polished block of the sulphide-bearing black phase. Standard measurement settings were applied; a $25 \mathrm{kV}, 5 \mathrm{nA}$ beam with a width of approximately $600 \mathrm{~nm}$, a working distance of approximately $22 \mathrm{~mm}$ and a 1000 count X-ray spectra (for more details see $[40,41]$ ). The whole sample area was analysed at a pixel resolution, i.e., a beam step size of $10 \mu \mathrm{m}(46 \times$ magnification with field size of $1500 \mu \mathrm{m})$, and a smaller selective area was also measured at a pixel resolution, i.e., beam step size of $1 \mu \mathrm{m}(238 \times$ magnification with field size of $300 \mu \mathrm{m}$ ). Data measurement used iMeasure 4.2 SR1 and data processing iDiscover 4.2SR1 and 4.3 software. Data processing involved checking the data and customising the mineral database to match the sample, with manual SEM validation by energy dispersive X-ray spectroscopy (EDS) to confirm identification when two minerals were chemically similar. Modal mineralogy, mineral association, and false colour images were output for the samples.

On the basis of petrographic observations, four of the samples were selected for high resolution textural and compositional investigation by electron-probe microanalysis (EPMA). Single points, traverses, and area mapping were performed on four standard sized carbon coated polished thin sections. Point and line analyses (for $\mathrm{As}, \mathrm{Bi}, \mathrm{Cd}, \mathrm{Co}, \mathrm{Cu}, \mathrm{Fe}, \mathrm{Mn}, \mathrm{Ni}, \mathrm{Pb}, \mathrm{S}, \mathrm{Sb}, \mathrm{Zn}$ ) were made on a JEOL JXA 8500 (JEOL, Tokyo, Japan) using a $1 \mu \mathrm{m}$ defocussed beam size at a working distance of $11 \mathrm{~mm}$, with a current of $20 \mathrm{nA}$ and an accelerating voltage of $15 \mathrm{kV}$. Mapping was performed under the same conditions, but in spot-mode with shorter counting times and a step length of $160 \mathrm{~nm}$.

For determining trace element abundances, whole-rock geochemistry was completed on splits from the XRD samples. A series of samples were sent to Bureau Veritas laboratories, Vancouver, Canada, for ICP-ES/MS to determine a trace element suite including Ag (package MA270), ICP-MS to determine REEs (package LF100), and fire assay to determine Au content (12 samples; package FA430). Submitted duplicates demonstrated excellent agreement, and the submitted blank did not show any anomalous trace elements. Internal laboratory duplicates had excellent agreement, as did the measurements of standard materials.

\section{Results}

\subsection{Macrocharacteristics of Vent Material}

The sampled hydrothermal vent fragments are highly heterogeneous. The rock is typically porous, with cavities lined with silica and sulphate crystals. The texture is chaotic, with billowing laminations of rusty and white sulphate, sulphide, and silicate minerals, grey clay dominated areas, and fine-grained black zones. Figure 4 illustrates representative type-examples of black and white material. In some samples, the disseminated sulphides amalgamate into interlocking lenses within a fine-grained black phase. Sulphides are not visible in the white phase. 

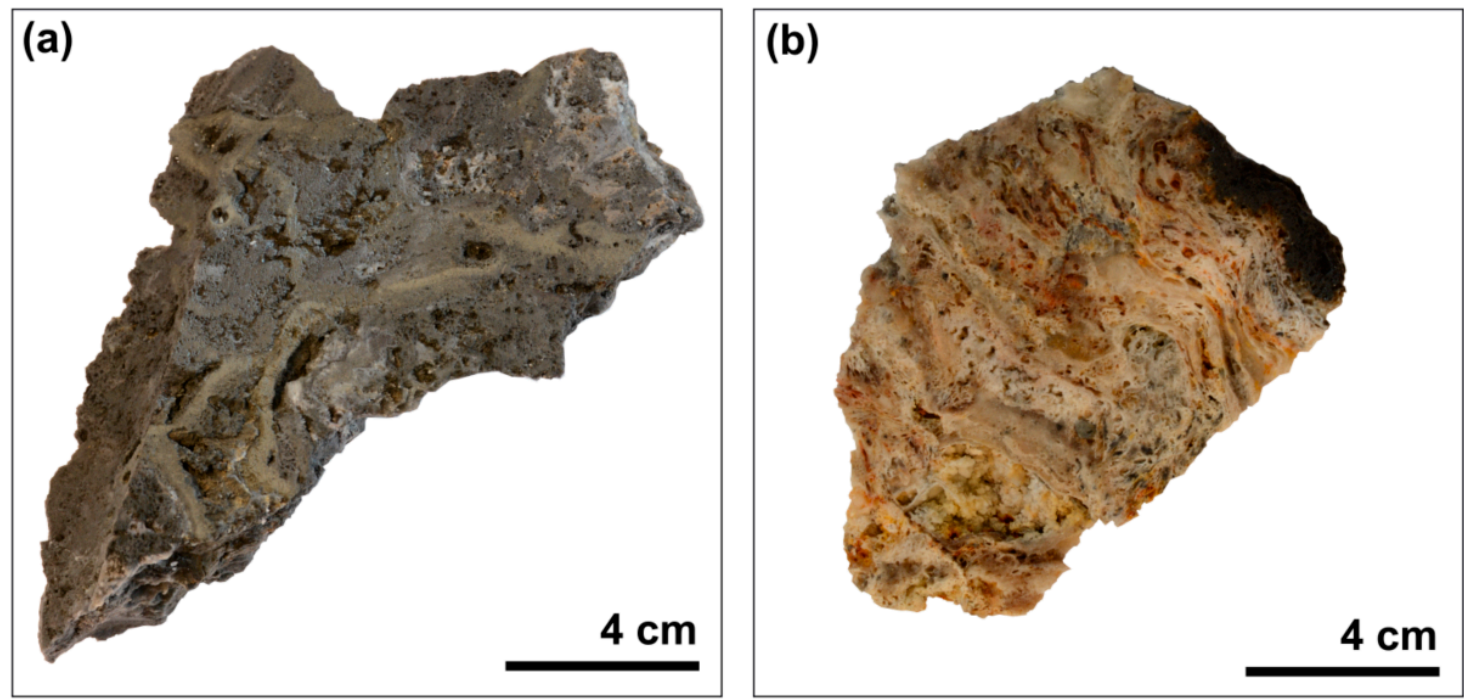

Figure 4. Cut (a) black and (b) white end-member hand samples of vent material; the majority of the material is a complex amalgamation of both. Sulphide lenses exist within the fine grained black groundmass, which also contains abundant disseminated sulphides.

\subsection{Mineralogy of Hydrothermal Vent Material after Petrography and XRD}

The white material is typically without sulphides, but it locally contains minor sphalerite as approximately $10 \mu \mathrm{m}$ thick grain coatings, and disseminated galena $(10-100 \mu \mathrm{m})$. Pyrite is present in limited quantities, typically as approximately $10 \mu \mathrm{m}$ isolated grains, but also associated with sphalerite in grains of up to $30 \mu \mathrm{m}$. Gangue is composed of amorphous silica, minor crystalline quartz, and euhedral barite crystals $100 \mathrm{~s}$ of microns in size. The black material contains higher levels of sulphide mineralisation, with pyrite, marcasite, isotropic isocubanite/"iss", chalcopyrite, sphalerite, galena, and pyrrhotite being present. Gangue material is composed of amorphous silica, crystalline quartz, and euhedral barite. The sulphides occur in two general forms; as coarser aggregates/grains in the black groundmass (e.g., Figure $5 \mathrm{a}-\mathrm{d}$ ), and as fine-grained sulphide lenses that are visible in hand samples (e.g., Figure 5e,f).

The lenses are typically composed of approximately $75 \%$ pyrite/marcasite, $15 \%$ sphalerite, and $10 \%$ chalcopyrite/isocubanite. Grains are commonly sub-angular and sized 1-50 $\mu \mathrm{m}$; pyrite/marcasite is usually the largest. Sphalerite and the copper phases are variably intergrown with each other, but also occur as distinct grains. Outside of the lens zones, sulphides are usually coarser, and occur as isolated grains and aggregates of sphalerite, isocubanite, chalcopyrite, and pyrite/marcasite (Figure 5a). Sphalerite exists as isolated grains of up to $200 \mu \mathrm{m}$, with variable amounts of sub-micron chalcopyrite inclusions, i.e., chalcopyrite disease [42] (Figure 5b), and as intergrowths with isocubanite. Isocubanite grain size is highly variable, but is mostly smaller than sphalerite, and no larger than $200 \mu \mathrm{m}$. It has locally degraded rims, commonly occurs in association with pyrite and sphalerite grains, and typically contains micron-scale exsolutions of chalcopyrite (Figure 5c) which also remain intact within the degraded rims. Chalcopyrite does exist without isocubanite, typically as sub- $10 \mu \mathrm{m}$ grains displaying alteration/tarnishing. Locally, blue phases are covellite with possible digenite, but these are very minor phases. Galena and pyrrhotite occur in only the most sulphide-rich samples, the latter typically being associated with pyrite. Pyrite may also tend towards boxwork-like (Figure 5g) and colloform (Figure 5h) structures, typically intergrown with sphalerite. Locally, chalcopyrite occurs within isocubanite as larger lamellae up to $10 \mu \mathrm{m}$, with strong preferred crystallographic orientation (Figure 5d). XRD generally corroborates petrographic observations (Table 1). Pyrrhotite is not abundant, and barite is the dominant sulphate in the material. Anhydrite, gypsum, talc, halite, and bassinite are also reported, particularly in greenish, sulphide 
poor clay-like samples. The significant presence of an amorphous phase means that results should be considered semi-quantitative rather than quantitative.
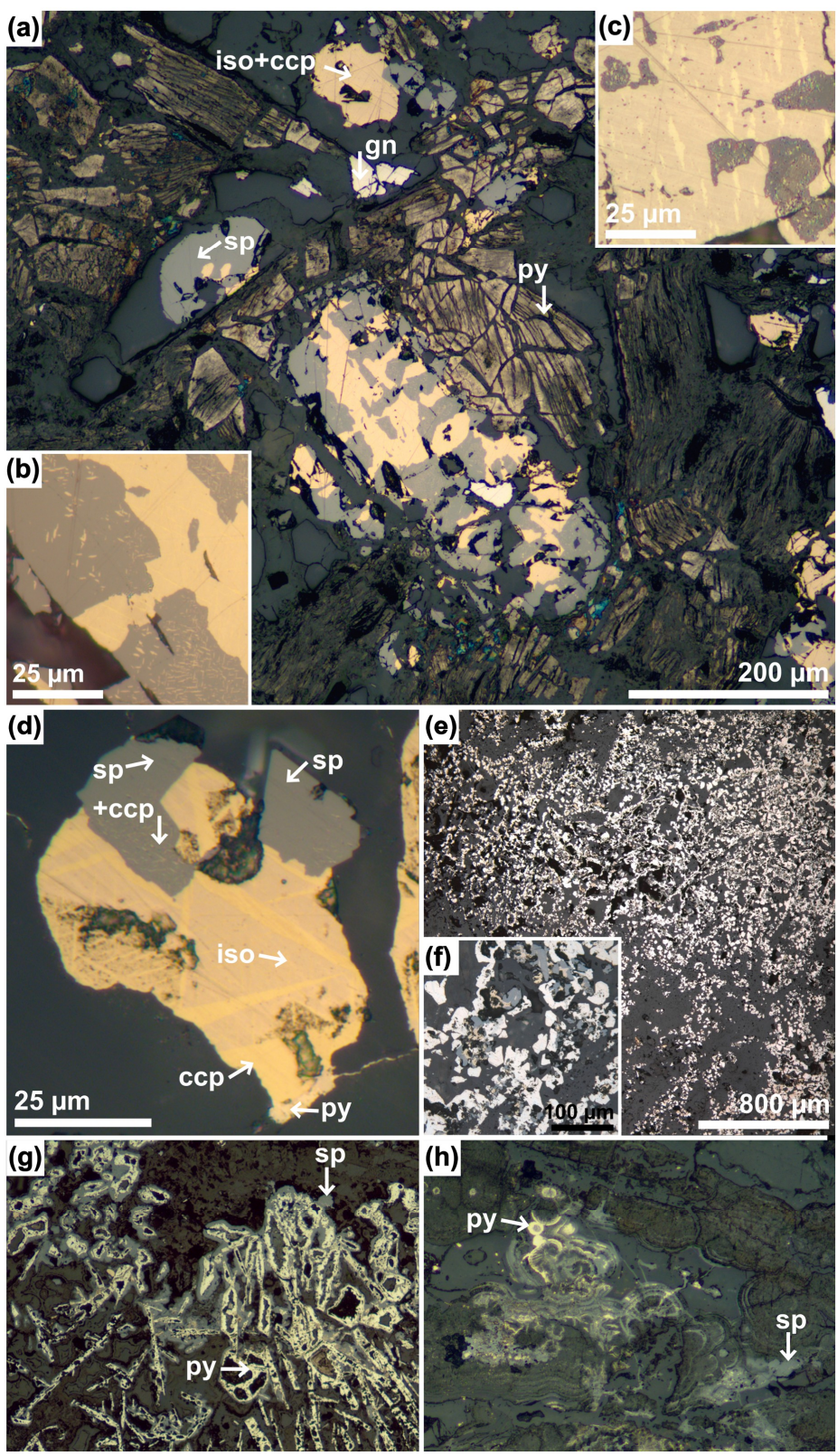

Figure 5. Examples of sulphide phases under reflected light. Mineral abbreviations after [43]. iso is isocubanite. (a) Overall mineral composition of a high-grade example of mineralised material, with dark grey gangue, mid-grey sphalerite, yellow/pink isocubanite and chalcopyrite, white galena and highly altered pyrite laths (sample viii); (b) Sphalerite (grey) is variably clean or affected by sub-micron scale chalcopyrite disease (yellow) (sample viii); (c) Typical isocubanite (pink yellow) grain containing micron-scale blebs of crystallographically controlled chalcopyrite exsolution lamellae (yellow) and grains of sphalerite (grey, variably exhibiting chalcopyrite disease) (sample ii); (d) Grain of isocubanite with exsolution lamellae of chalcopyrite in two crystallographic orientations, degraded chalcopyrite-bearing patches and variably clean sphalerite (sample $x i$ ). Localised pyrite occurs in the assemblage; (e,f) Mineralogy of sulphide lenses (grey sphalerite, yellow chalcopyrite/isocubanite, white pyrite/marcasite) in black material (sample iv(b)); (g) Boxwork-like and (h) colloform pyrite with sphalerite from sample $i$. 
Table 1. Mineralogy of samples after XRD analysis. ? is uncertain, + is $0-5 \%,++$ is $5-15 \%,+++$ is $15 \%$ and over. Mineral abbreviations after [43]. amo is amorphous phase; iso is isocubanite.

\begin{tabular}{|c|c|c|c|c|c|c|c|c|c|c|c|c|c|c|c|c|}
\hline Sample & Description & brt & $q t z$ & amo & $p y$ & $m r c$ & $s p$ & iso & $c c p$ & $g n$ & po & anh & $g p$ & $t l c$ & $h l$ & bss \\
\hline$i$ & dark rusty & ++ & & ++ & ++ & +++ & ++ & + & + & $?$ & + & & & & & \\
\hline$i i$ & dark rusty & +++ & & + & +++ & +++ & + & + & + & & & & & & & \\
\hline$i i i$ & mixed & +++ & & + & & & & & & & & & & & & \\
\hline$i v(w)$ & white & +++ & & + & & & & & & & & & & & & \\
\hline$i v(b)$ & dark rusty & +++ & & ++ & + & + & ++ & + & ++ & + & + & & & & & \\
\hline$v$ & white/grey & +++ & & + & & & & & & & & & & & & \\
\hline$v i$ & mixed & +++ & +++ & + & & & & & & & & & & & & \\
\hline vii & grey rusty & ++ & +++ & + & + & + & + & + & + & + & & & & & & \\
\hline viii & dark rusty & + & +++ & + & + & ++ & +++ & ++ & + & + & & & & & & \\
\hline$i x$ & grey rusty & +++ & +++ & + & & & $?$ & & & & & & & & & \\
\hline$x$ & $\begin{array}{c}\text { mixed } \\
\text { rusty }\end{array}$ & +++ & +++ & + & & & $?$ & & & + & & & & & & \\
\hline$x i$ & mixed & + & +++ & + & + & & + & & & & & & & & & \\
\hline$x i i$ & grey & & & + & & & + & & & & & +++ & ++ & +++ & + & \\
\hline xiii & green & & & +++ & $?$ & & & & + & & & & & +++ & ++ & \\
\hline$x i v$ & green & & & +++ & $?$ & & & & + & & & & & +++ & ++ & \\
\hline$x v$ & mixed & & & + & & & + & & & & & +++ & +++ & & & +++ \\
\hline
\end{tabular}

\subsection{QEMSCAN}

QEMSCAN was used to generate mineralogical data pertaining to black vent material. Modal mineralogy (by density weighted mineral mass \% and mineral volume area \%) and minimum/average/maximum grain size are summarised in Table 2 from a Fieldscan of the complete block performed at $10 \mu \mathrm{m}$ X-ray analysis resolution, and a smaller Fieldscan of a targeted area performed at $1 \mu \mathrm{m} X$-ray analysis resolution. The block was made from sample $i v(b)$.

Table 2. Mineralogy of mineralised material after QEMSCAN analysis, performed at 10 and $1 \mu \mathrm{m}$ pixel resolution, i.e., beam step size. Mineralogical data is normalised and is reported to the nearest $100 \mathrm{ppm}$. A minimum grain size of $\leq 15$ or $\leq 1.5 \mu \mathrm{m}$ is a product of scan resolution (fields are overlapped for stitching).

\begin{tabular}{|c|c|c|c|}
\hline & & $10 \mu \mathrm{m}$ & $1 \mu \mathrm{m}$ \\
\hline \multirow{3}{*}{ Measurement } & Measurement Mode & Field Image & Field Image \\
\hline & Measurement Area (mm) & $20 \times 28$ & $3 \times 3$ \\
\hline & No. X-ray Analysis Points & $3,831,192$ & $8,598,413$ \\
\hline \multirow{9}{*}{$\begin{array}{l}\text { Mineral mass } \\
\quad(w \mathrm{t} \%)\end{array}$} & Quartz & 48.08 & 51.32 \\
\hline & Pyrite/Marcasite & 43.69 & 35.23 \\
\hline & Chalcopyrite & 1.68 & 4.75 \\
\hline & Isocubanite & 0.68 & 3.73 \\
\hline & Chalcocite/Covellite & 0.01 & 0.19 \\
\hline & Sphalerite & 3.14 & 3.59 \\
\hline & Galena & 0.05 & 0.02 \\
\hline & Barite & 2.61 & 1.15 \\
\hline & Others & 0.08 & 0.04 \\
\hline \multirow{9}{*}{$\begin{array}{l}\text { Mineral volume } \\
\quad(\text { area \%) }\end{array}$} & Quartz & 61.47 & 63.48 \\
\hline & Pyrite/Marcasite & 29.27 & 22.83 \\
\hline & Chalcopyrite & 1.92 & 4.95 \\
\hline & Isocubanite & 0.48 & 2.57 \\
\hline & Chalcocite/Covellite & 0.01 & 0.13 \\
\hline & Sphalerite & 4.82 & 5.17 \\
\hline & Galena & 0.03 & 0.01 \\
\hline & Barite & 1.95 & 0.83 \\
\hline & Others & 0.06 & 0.03 \\
\hline \multirow{9}{*}{$\begin{array}{c}\text { Grain size } \\
\min / \operatorname{avg} / \max \\
\text { (nearest } \mu \mathrm{m} \text { ) }\end{array}$} & Quartz & $\leq 15 / 73 / 1511$ & $\leq 1.5 / 28 / 226$ \\
\hline & Pyrite/Marcasite & $\leq 15 / 41 / 388$ & $\leq 1.5 / 9 / 109$ \\
\hline & Chalcopyrite & $\leq 15 / 22 / 133$ & $\leq 1.5 / 5 / 63$ \\
\hline & Isocubanite & $\leq 15 / 23 / 85$ & $\leq 1.5 / 4 / 43$ \\
\hline & Chalcocite/Covellite & $\leq 15 / 22 / 75$ & $\leq 1.5 / 17 / 39$ \\
\hline & Sphalerite & $\leq 15 / 23 / 145$ & $\leq 1.5 / 11 / 59$ \\
\hline & Galena & $\leq 15 / 18 / 60$ & $\leq 1.5 / 6 / 14$ \\
\hline & Barite & $\leq 15 / 71 / 578$ & $\leq 1.5 / 26 / 137$ \\
\hline & Others & $\leq 15 / 16 / 60 / 60$ & $\leq 1.5 / 3 / 16$ \\
\hline
\end{tabular}


The field image mineral maps are shown in Figures 6 and 7. The pyrite-dominated lenses are well defined, with barite-rich areas clearly demarcated. The porosity can be inferred from the background, i.e., epoxy resin. QEMSCAN is also able to detect the amorphous silicate phase, reporting it as quartz. In this sample, sphalerite grains are finer than the copper bearing phases, and occur more discretely than observed in Figure 5. Figure 7 further corroborates petrography observations that chalcopyrite is intimately associated with isocubanite.

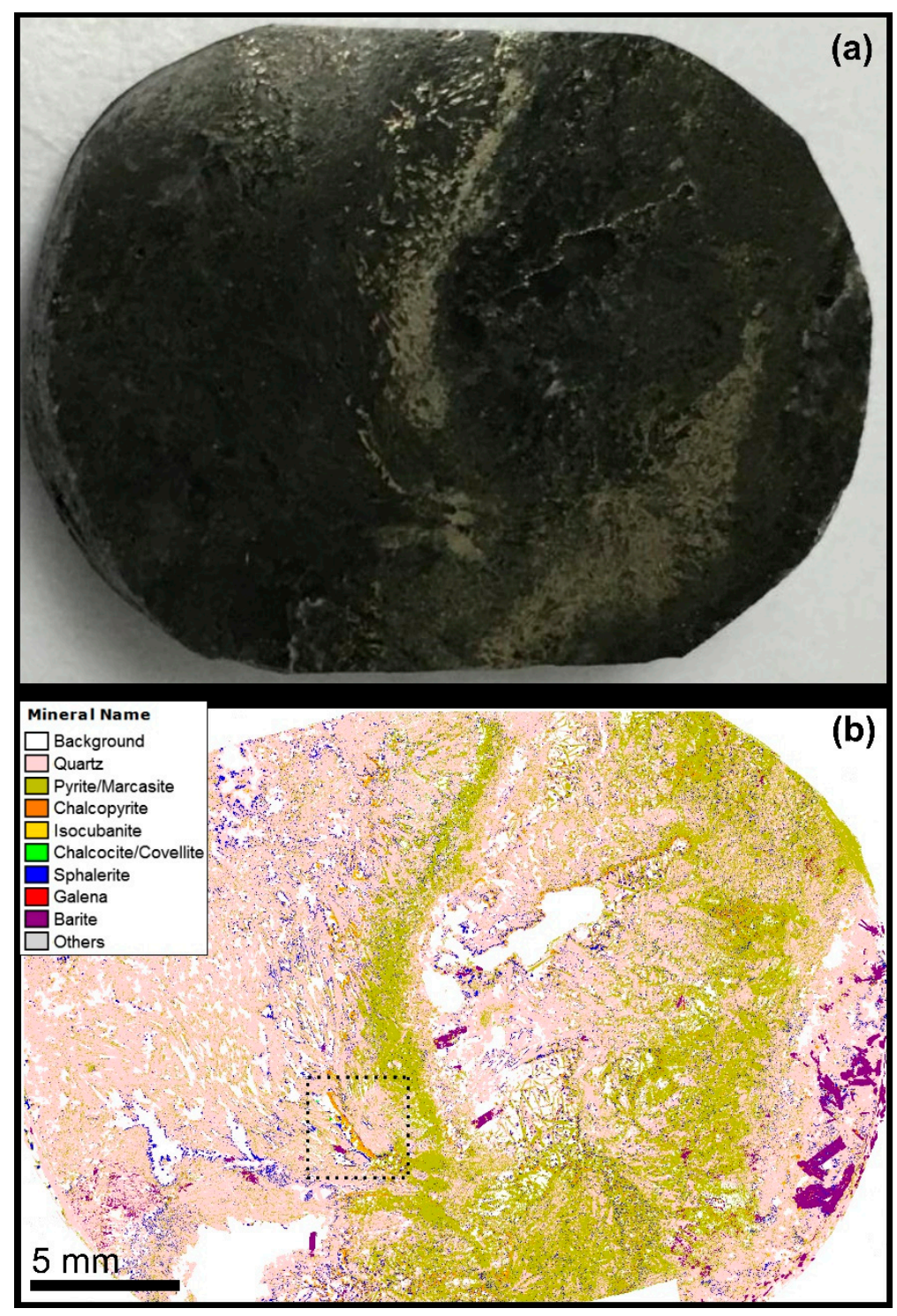

Figure 6. (a) Polished block of black material; (b) false colour QEMSCAN field scan at $10 \mu \mathrm{m}$ pixel spacing with the area of Figure 7a demarcated. The block was made from sample $i v(b)$.

However, the degraded isocubanite chalcopyrite-bearing rims are reported only as chalcopyrite. As with all beam-based analytical techniques, generated data is strongly affected by beam size, which determines the minimum detectable grain size-a coarse beam, or pixel resolution will fail to detect an instance of fine mineralogical variation. This is demonstrated in Figure $7 \mathrm{~b}-\mathrm{e}$, where the ultra-fine laminations of chalcopyrite in isocubanite are identified but not spatially resolved, and where micro-inclusions of chalcopyrite in sphalerite are missed completely. 


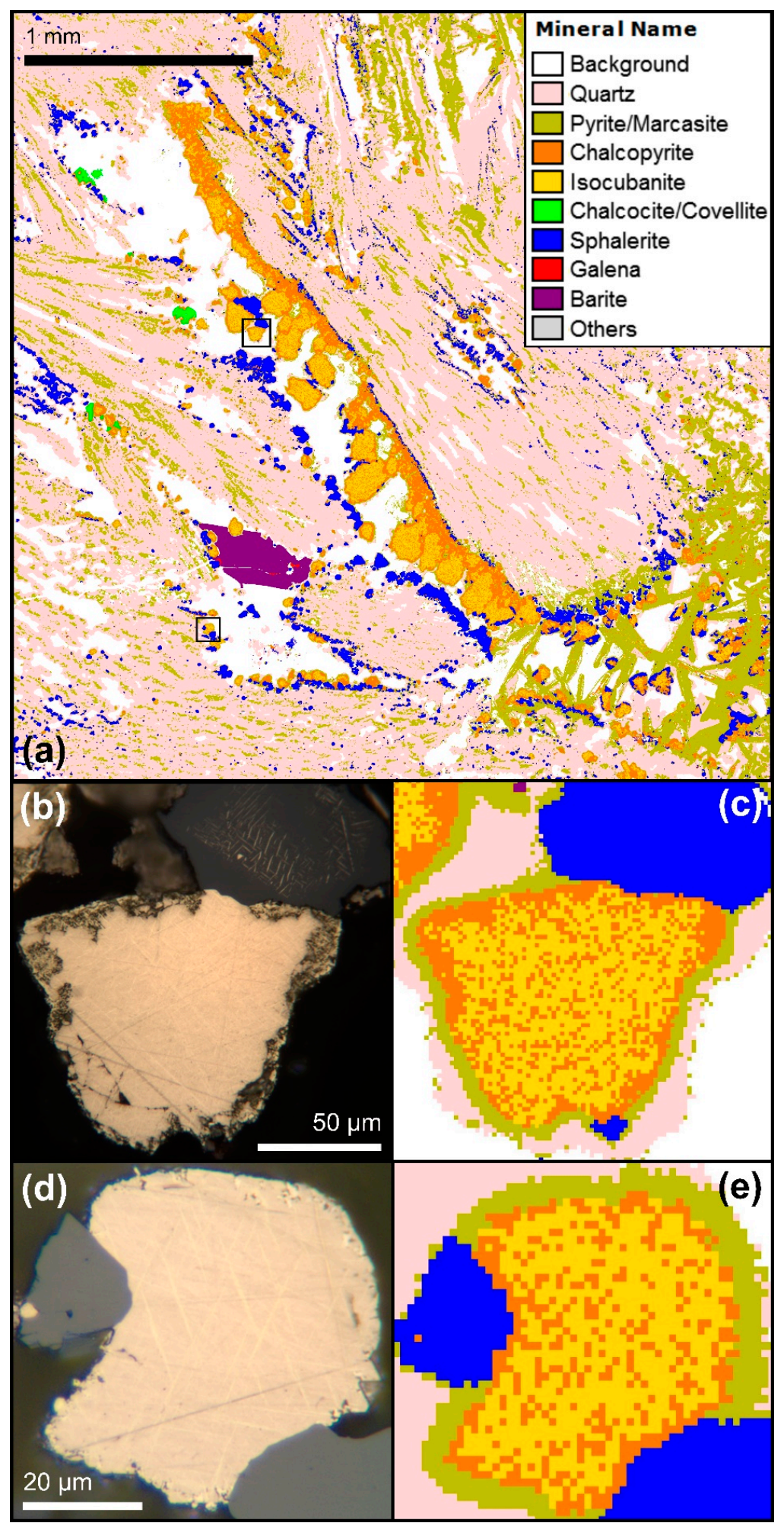

Figure 7. (a) False colour QEMSCAN field scan at $1 \mu \mathrm{m}$ pixel spacing. Cu-sulphide phases are coarser than sphalerite, and consist of intergrown chalcopyrite and isocubanite. Pyrite occurs as ultrafine disseminations throughout the gangue, and as coarser laths in the upper right; (b-e) QEMSCAN cannot properly resolve variations in $\mathrm{Cu}-\mathrm{Fe}-$-sulphides because the crystallographically controlled exsolution lamellae are smaller than EDS resolution, and chalcopyrite and isocubanite signals become merged. Sub-micron chalcopyrite inclusions in sphalerite (c) are missed completely. A well-defined pyrite rim under QEMSCAN is not as apparent in reflected light microscopy. 
Table 3 summarises the compositional and mineral association (i.e., neighbouring pixels of differing mineralogy) data produced by QEMSCAN at a $1 \mu \mathrm{m}$ resolution of the $\mathrm{Cu}$-rich area (Figure 7). For example, sphalerite comprises $3.59 \mathrm{wt} \%$ and $5.17 \%$ volume of the scanned area, with an average grain size of $10.7 \mu \mathrm{m}$. A percentage of $66.5 \%$ of sphalerite occurs with pyrite/marcasite; the inverse is not true, with the majority $(65.98 \%)$ of pyrite/marcasite occurring with quartz. Isocubanite occurs almost exclusively with chalcopyrite $(96.68 \%)$, whereas only $62.89 \%$ of chalcopyrite is associated with isocubanite. QEMSCAN reports that almost all of the remaining chalcopyrite occurs with pyrite/marcasite and sphalerite.

Table 3. Summary (reading down, then left) of mineralogical associations of mineralised material identified by QEMSCAN ( $1 \mu \mathrm{m}$ resolution). Mineral abbreviations after [43]. iso is isocubanite. $b / g$ is background, i.e., epoxy resin (voids/cavities/pores).

\begin{tabular}{ccccccccccc}
\hline & $\boldsymbol{b} / \boldsymbol{g}$ & $\boldsymbol{q t z}$ & $\boldsymbol{p y} / \boldsymbol{m r c}$ & $\boldsymbol{c c p}$ & $\boldsymbol{i s o}$ & $\boldsymbol{c c}$ & $\boldsymbol{s p l}$ & $\boldsymbol{g n}$ & $\boldsymbol{b r t}$ & other \\
\hline wt $\%$ & $\mathrm{n} / \mathrm{a}$ & 51.32 & 35.23 & 4.75 & 3.73 & 0.19 & 3.59 & 0.02 & 1.15 & 0.04 \\
vol \% & $\mathrm{n} / \mathrm{a}$ & 63.48 & 22.83 & 4.95 & 2.57 & 0.13 & 5.17 & 0.01 & 0.83 & 0.03 \\
size $\mu \mathrm{m}$ & $\mathrm{n} / \mathrm{a}$ & 28 & 9 & 5 & 4 & 17 & 11 & 6 & 26 & 3 \\
b/g & 0.00 & 20.99 & 10.52 & 1.08 & 0.47 & 28.17 & 7.10 & 2.74 & 18.57 & 22.06 \\
qtz & 58.97 & 0.00 & 65.98 & 0.61 & 0.01 & 0.00 & 12.49 & 3.65 & 30.77 & 22.41 \\
$\mathrm{py} / \mathrm{mrc}$ & 33.86 & 75.55 & 0.00 & 27.67 & 2.78 & 0.56 & 66.50 & 47.03 & 39.33 & 24.70 \\
ccp & 1.25 & 0.25 & 9.87 & 0.00 & 96.68 & 71.07 & 13.49 & 0.68 & 0.66 & 9.45 \\
iso & 0.35 & 0.00 & 0.65 & 62.89 & 0.00 & 0.15 & 0.08 & 0.00 & 0.01 & 0.00 \\
cc & 0.27 & 0.00 & 0.00 & 0.59 & 0.00 & 0.00 & 0.00 & 0.00 & 0.00 & 0.03 \\
spl & 4.24 & 2.66 & 12.35 & 7.02 & 0.06 & 0.00 & 0.00 & 5.48 & 2.79 & 5.78 \\
gn & 0.01 & 0.00 & 0.03 & 0.00 & 0.00 & 0.00 & 0.02 & 0.00 & 1.94 & 0.59 \\
brt & 0.72 & 0.43 & 0.48 & 0.02 & 0.00 & 0.00 & 0.18 & 36.07 & 0.00 & 14.98 \\
other & 0.34 & 0.12 & 0.12 & 0.13 & 0.00 & 0.05 & 0.15 & 4.34 & 5.93 & 0.00 \\
\hline
\end{tabular}

\subsection{EPMA}

EPMA point analyses (Table 4 contains data from a representative grain) confirmed by mineral chemistry that $\mathrm{Cu}-\mathrm{Fe}$-sulphide phases are chalcopyrite and isocubanite, or "iss" (e.g., [19]). The Fe content is appropriate, and the consistently slightly low $\mathrm{Cu}$ content could be a result of consistently slightly low totals. Figure 8 displays maps for back scattered electron (BSE) and selected elements for a particle illustrated in Figure 5d, notable for its large chalcopyrite lamellae. These are clearly visible as elevated $\mathrm{Cu}$ regions, with isocubanite containing higher Fe. The degraded isocubanite chalcopyrite-bearing rims/patches report higher $\mathrm{Cu}$ than intact isocubanite. Areas identified as pyrite contain no $\mathrm{Cu}$, and elevated Fe and S. S is relatively consistent throughout the sulphides. Zn occurs only in sphalerite, which also displays slightly elevated $\mathrm{Fe}$, and $\mathrm{Cu}$ in the areas known to contain chalcopyrite disease. Sphalerite also appears to contain weakly elevated Mn.

\subsection{Geochemistry of Vent Material}

Fire assay (for $\mathrm{Au}$ ) and ICP-ES/MS (for remaining) whole rock compositional data are given for selected elements in Table 5. There is a strong correlation between $\mathrm{Cu}$ and $\mathrm{Zn}$, with several samples containing over $0.5 \%$ and $1 \%$ respectively, and one sample containing $2.05 \%$ and $7.38 \%$, respectively. $\mathrm{Cu}$ and Fe show good correlation, as do $\mathrm{As}$ and $\mathrm{Sb}$, and $\mathrm{Au}$ and $\mathrm{Sb}$. Ba shows little correlation with the other analysed elements, but only the very low Ba samples that contain any $\mathrm{Cu}$ or $\mathrm{Zn}$, and only the very low $\mathrm{Cu}$ samples that contain any Ba. Low Ba content in general is likely a result of silica dominating over barite in the gangue phase, with the sulphide assemblage providing the majority of the S. Little correlation exists between the other elements. Over half of the analysed samples contain significant amounts of $\mathrm{Au}$ and Ag (when compared to average Au and Ag VMS grades [6]), in a roughly proportional amount, with one sample containing $6.3 \mathrm{ppm}$ and $339.7 \mathrm{ppm}$, respectively. 
Table 4. Electron probe micro-analysis (EPMA) point analyses with mineral identification and elemental wt \%. Mineral abbreviations after [43]. iso is isocubanite. Point locations are indicated in Figure 7. Points 11 and 12 are from an adjacent galena crystal. Element detection limits (ppm) are provided for each analysis point in Appendix A, Table A1.

\begin{tabular}{cccccccccccccc}
\hline Point & As & S & Mn & Pb & Fe & Bi & Co & Cd & Ni & Sb & Cu & Zn & Total \\
\hline 1 ccp & 0.02 & 34.36 & 0.01 & 0.02 & 31.45 & $<\mathrm{DL}$ & 0.04 & 0.03 & $<\mathrm{DL}$ & 0.02 & 30.76 & 0.40 & 97.10 \\
$2 \mathrm{ccp}$ & $<\mathrm{DL}$ & 34.26 & 0.01 & 0.03 & 32.11 & $<\mathrm{DL}$ & 0.04 & 0.01 & $<\mathrm{DL}$ & $<\mathrm{DL}$ & 30.30 & 0.41 & 97.16 \\
$3 \mathrm{ccp}$ & $<\mathrm{DL}$ & 34.14 & 0.00 & $<\mathrm{DL}$ & 31.87 & $<\mathrm{DL}$ & 0.06 & 0.02 & $<\mathrm{DL}$ & 0.01 & 30.33 & 0.44 & 96.88 \\
$4 \mathrm{ccp}$ & $<\mathrm{DL}$ & 33.67 & 0.02 & 0.03 & 31.60 & $<\mathrm{DL}$ & 0.07 & 0.01 & $<\mathrm{DL}$ & 0.04 & 30.51 & 0.60 & 96.56 \\
$5 \mathrm{spl}$ & $<\mathrm{DL}$ & 32.21 & 0.45 & $<\mathrm{DL}$ & 15.50 & $<\mathrm{DL}$ & 0.03 & 0.17 & $<\mathrm{DL}$ & $<\mathrm{DL}$ & 0.25 & 46.69 & 95.29 \\
$6 \mathrm{spl}$ & $<\mathrm{DL}$ & 32.01 & 0.43 & 0.06 & 15.97 & $<\mathrm{DL}$ & 0.03 & 0.14 & 0.02 & $<\mathrm{DL}$ & 0.29 & 46.39 & 95.33 \\
$7 \mathrm{spl}$ & $<\mathrm{DL}$ & 32.81 & 0.55 & $<\mathrm{DL}$ & 17.52 & $<\mathrm{DL}$ & 0.02 & 0.14 & 0.02 & 0.02 & 2.99 & 42.03 & 96.09 \\
$8 \mathrm{spl}$ & $<\mathrm{DL}$ & 32.90 & 0.61 & 0.11 & 17.87 & $<\mathrm{DL}$ & 0.02 & 0.10 & 0.02 & $<\mathrm{DL}$ & 3.54 & 42.01 & 97.18 \\
$9 \mathrm{spl}$ & $<\mathrm{DL}$ & 31.78 & 0.61 & 0.16 & 15.91 & $<\mathrm{DL}$ & 0.01 & 0.08 & 0.01 & $<\mathrm{DL}$ & 0.89 & 45.10 & 94.56 \\
$10 \mathrm{spl}$ & $<\mathrm{DL}$ & 32.82 & 0.65 & 0.00 & 16.88 & $<\mathrm{DL}$ & 0.01 & 0.10 & $<\mathrm{DL}$ & 0.03 & 1.80 & 43.94 & 96.22 \\
$11 \mathrm{gn}$ & $<\mathrm{DL}$ & 12.89 & $<\mathrm{DL}$ & 83.41 & 0.53 & $<\mathrm{DL}$ & $<\mathrm{DL}$ & 0.13 & 0.02 & $<\mathrm{DL}$ & 0.57 & 0.18 & 97.73 \\
$12 \mathrm{gn}$ & $<\mathrm{DL}$ & 12.78 & $<\mathrm{DL}$ & 83.92 & 0.32 & $<\mathrm{DL}$ & $<\mathrm{DL}$ & 0.17 & $<\mathrm{DL}$ & 0.05 & 0.24 & 0.07 & 97.55 \\
$13 \mathrm{iso}$ & 0.01 & 34.26 & 0.08 & 0.02 & 43.00 & $<\mathrm{DL}$ & 0.06 & 0.02 & $<\mathrm{DL}$ & 0.01 & 18.81 & 0.82 & 97.09 \\
$14 \mathrm{iso}$ & $<\mathrm{DL}$ & 34.24 & 0.07 & 0.15 & 41.45 & $<\mathrm{DL}$ & 0.05 & 0 & 0.04 & 0.05 & 19.99 & 2.10 & 98.13 \\
\hline
\end{tabular}
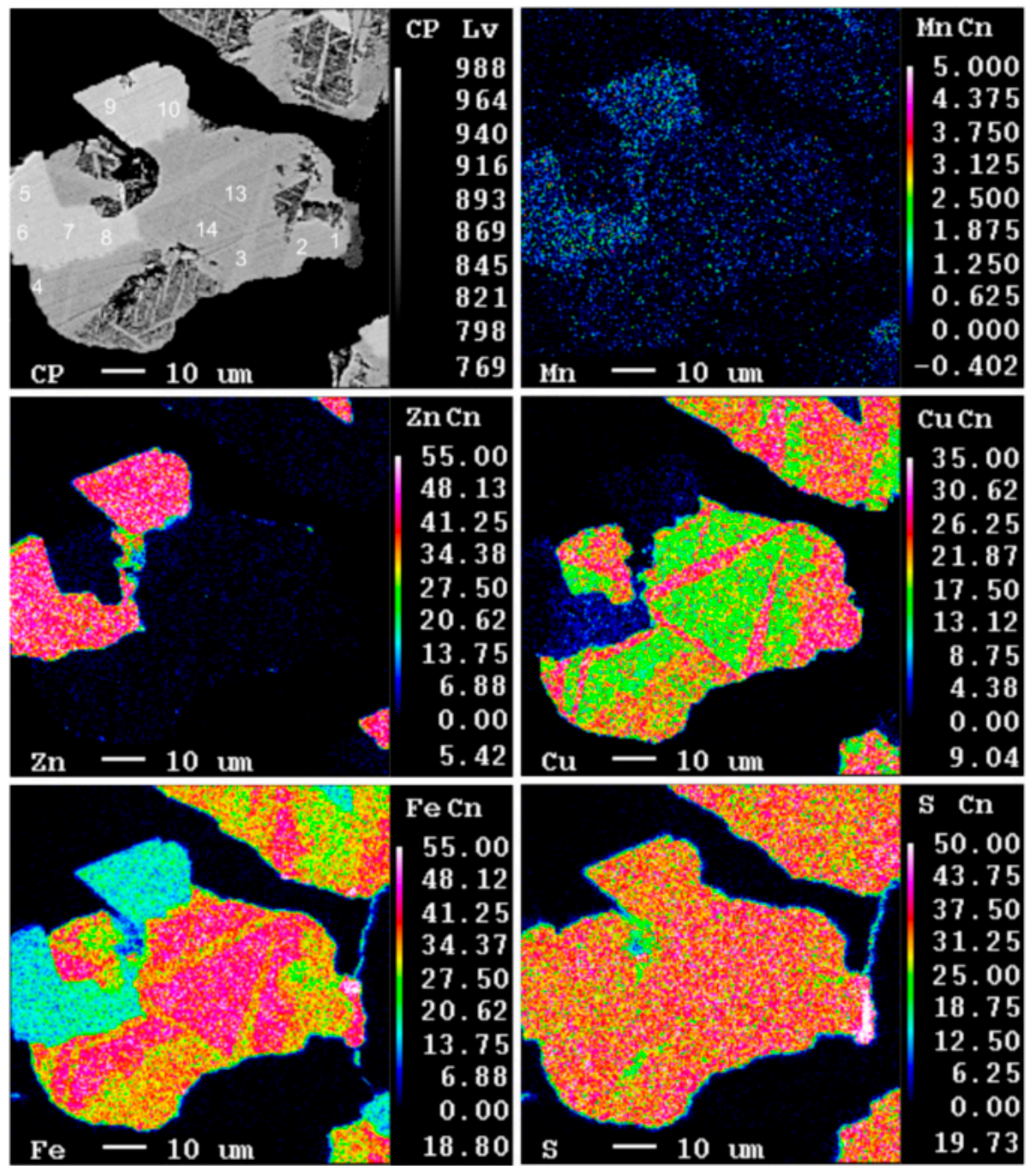

Figure 8. EPMA maps of back scattered electron (BSE), $\mathrm{Mn}, \mathrm{Zn}, \mathrm{Cu}, \mathrm{Fe}$, and $\mathrm{S}$, with colour scales. The featured particle appears in Figure $4 \mathrm{~d}$, and the analyses points of Table 4 are marked. 
Table 5. Selected whole-rock geochemistry for the 15 selected vent samples. DL is the detection limit. na is not analysed.

\begin{tabular}{|c|c|c|c|c|c|c|c|c|c|c|c|c|c|c|c|}
\hline & $\mathrm{Cu}$ & Zn & $\mathrm{Fe}$ & $S$ & $\mathrm{Au}$ & Ag & Mo & $\mathrm{Ni}$ & Co & Mn & $\mathbf{P b}$ & As & $\mathrm{Cd}$ & $\mathrm{Sb}$ & $\mathbf{B a}$ \\
\hline Unit & $\%$ & $\%$ & $\%$ & $\%$ & ppm & ppm & ppm & ppm & ppm & ppm & ppm & ppm & ppm & ppm & ppm \\
\hline DL & $5 \times 10^{-5}$ & 0.0005 & 0.01 & 0.05 & 0.005 & 0.5 & 0.5 & 0.5 & 1 & 5 & 0.5 & 5 & 0.5 & 0.5 & 5 \\
\hline$i$ & 0.55 & 1.16 & 10.26 & 11.17 & 2.15 & 20.3 & 5.5 & 1034 & 12 & 402 & 1847 & 575 & 34.8 & 30.6 & 193 \\
\hline$i i$ & 1.19 & 1.49 & 18.9 & 19 & 2.42 & 81.5 & 18.3 & 375 & 8 & 1283 & 313 & 2880 & 48.4 & 34 & 66 \\
\hline$i i i$ & 0.02 & 0.04 & 0.8 & 0.27 & 2.51 & 139.9 & 1.5 & 1604 & 2 & 164 & 460.3 & 259 & 0.7 & 15.8 & 5612 \\
\hline$i v(w)$ & 0.01 & 0.01 & 0.39 & 0.31 & 5.33 & 7.3 & 3.9 & 846.8 & 1 & 16 & 6 & 221 & $<0.5$ & 8.3 & 8124 \\
\hline$i v(b)$ & 0.76 & 1.34 & 3.6 & 5.42 & 4.03 & 130.4 & 13.2 & 1818 & 5 & 341 & 7367 & 1387 & 29.5 & 84.2 & 252 \\
\hline$v$ & 0.03 & 0.21 & 0.09 & 0.32 & 6.3 & 339.7 & 0.7 & 1043 & $<1$ & 26 & 103 & 343 & 5.7 & 48.7 & 4513 \\
\hline$v i$ & 0.03 & 0.08 & 0.9 & 0.72 & 3.1 & 24.9 & 8.2 & 1574 & 1 & 204 & 103.5 & 777 & 1.1 & 63.4 & 2855 \\
\hline$v i i$ & 0.55 & 0.56 & 5.83 & 5.33 & 1.07 & 12.2 & 18.8 & 1189 & 3 & 563 & 7808 & 364 & 13.9 & 17.8 & 323 \\
\hline viii & 2.05 & 7.38 & 21.27 & 18.43 & 0.05 & 18.2 & 6.1 & 469.9 & $<1$ & 777 & 37,418 & 5 & 186.4 & 3.1 & 91 \\
\hline$i x$ & 0.09 & 0.18 & 1.72 & 0.86 & 3.15 & 41.7 & 6 & 1020 & 2 & 468 & 605.9 & 409 & 3.9 & 38.9 & 2079 \\
\hline$x$ & 0.09 & 0.17 & 1.46 & 1.16 & 3.76 & 42.5 & 11.7 & 1998 & $<1$ & 88 & 568.9 & 1129 & 2.2 & 69.1 & 1650 \\
\hline$x i$ & 0.13 & 0.23 & 1.85 & 1.03 & 0.28 & 4.9 & 11.2 & 1463 & 3 & 392 & 1362 & 181 & 4.4 & 6.9 & 2307 \\
\hline$x i i$ & 0.14 & 0.06 & 2.25 & 14.25 & $n a$ & 0.8 & $<0.5$ & 39.8 & 4 & 159 & 24.2 & $<5$ & 2.3 & 0.6 & 204 \\
\hline xiii & 0.51 & 0.02 & 4.65 & 3.02 & na & 1.1 & $<0.5$ & 14.9 & 5 & 521 & 20.9 & 12 & $<0.5$ & $<0.5$ & 280 \\
\hline$x i v$ & 0.43 & 0.03 & 4.4 & 3.58 & na & 0.9 & $<0.5$ & 21 & 5 & 495 & 33.3 & 13 & $<0.5$ & $<0.5$ & 165 \\
\hline$x v$ & 0.08 & 0.08 & 1.34 & 18.03 & $n a$ & $<0.5$ & $<0.5$ & 27.1 & 2 & 60 & 34.7 & 6 & 2.6 & 0.5 & 164 \\
\hline
\end{tabular}


Country rock samples of basalt and mudstone collected from the flanks of Loki's Castle were also analysed, for regional context. REE-signatures (after ICP-MS) are shown in Figure 9. The basalt sample is slightly REE-enriched compared to chondrite, with a flat signature and a slightly light REE-enriched altered rim compared to an unaltered core. The mudstone is enriched in light REEs over heavy REEs. The analysed vent material is essentially barren of REEs, with $\mathrm{Pr}, \mathrm{Nd}, \mathrm{Sm}, \mathrm{Tb}, \mathrm{Dy}, \mathrm{Ho}, \mathrm{Er}, \mathrm{Tm}, \mathrm{Yb}$, and $\mathrm{Lu}$ being largely below the detection limits. $\mathrm{La}, \mathrm{Ce}, \mathrm{Eu}$, and $\mathrm{Gd}$ are typically $0.5-10$ rock/chondrite, with a slightly positive Eu anomaly.

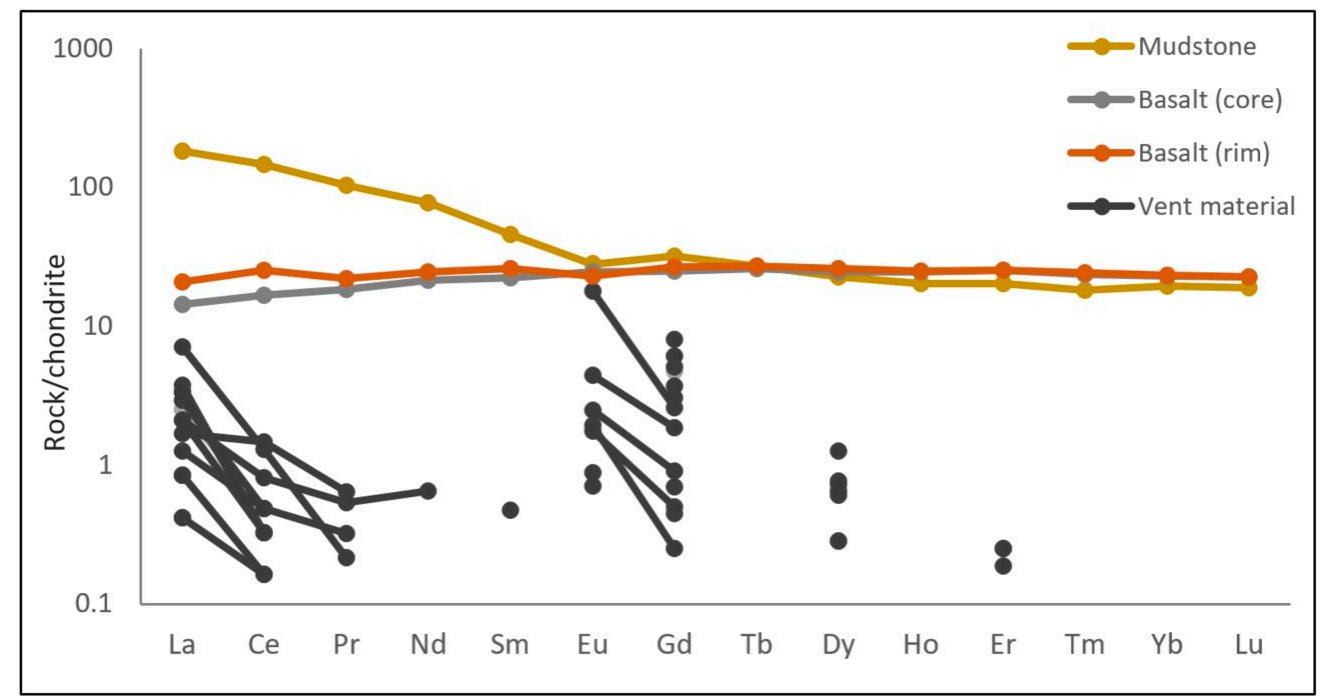

Figure 9. Rare earth element (REE) composition of basalt, mudstone, and sulphide-bearing grab samples from the Loki's Castle mound flanks (chondrite normalised after [44]).

\section{Discussion}

\subsection{Composition of Mineralised Material from the AMOR}

The initial objective of this study was to provide an in-depth summary of the mineralisation of a hydrothermal vent site on the AMOR. Two distinct lithological end members were identified; a sulphide-deficient generally crystalline white phase dominated by sulphates and silica, and a sulphide-bearing subcrystalline black phase. The black material contains sulphides, both as very fine-grained lenses, and as coarser aggregates and intergrowths disseminated throughout the sample material. Sulphide mineralisation consists of pyrite, marcasite, chalcopyrite, isocubanite, and sphalerite, with minor pyrrhotite and galena. Isocubanite, the dominant $\mathrm{Cu}-\mathrm{Fe}-\mathrm{S}$ phase observed in this study, is not mentioned in the limited existing research pertaining to Loki's Castle [8,22,45]. Micron-scale intergrowths of the $\mathrm{Cu}$ - and $\mathrm{Zn}$-bearing phases are extremely common. Sub-micron lamellae of chalcopyrite within isocubanite occur as a result of sub-solidus exsolution. Chalcopyrite disease (after [42]) theoretically occurs within sphalerite as a result of replacement/co-precipitation of Fe-rich sphalerite by/with chalcopyrite + Fe-poor sphalerite with minimal solid state diffusion, though it is difficult to definitively map changes in Fe content in sphalerite in these samples, due to the scale of the generated inclusions. Although most REE analyses were below detection limits, the signature of Loki's Castle vent material is comparable to other published REE signatures for SMS and VMS deposits (e.g., $[16,46,47])$, i.e., extremely depleted. The sedimentary signature is similar to the North American Shale complex, with elevated light REE and low heavy REE [48].

\subsubsection{Mineralogical Implications}

The minerals observed are indicative of a relatively high temperature regime [7], which correlates with measured fluid temperatures of up to $320^{\circ} \mathrm{C}$ [8]. Indeed, it is suggested that exsolved chalcopyrite 
in "iss" represents slow cooling below $450{ }^{\circ} \mathrm{C}$, as this is below the $500{ }^{\circ} \mathrm{C}$ miscibility gap $[19,49]$. Based on the discussion of the oxidative metal precipitation process [13], the $\mathrm{Cu}-\mathrm{Fe}-\mathrm{S}$ minerals observed in the Loki's Castle material are possibly relatively immature. Bivalent Fe is the first Fe species removed from the hydrothermal fluid which initially leads to the formation of isocubanite (1), with a progressive concentration of $\mathrm{Cu}$ as chalcopyrite with dropping temperature, which is observed as exsolutions and overgrowths (2), and eventually bornite (3) [13]. Non-stoichiometric $\mathrm{Cu}$ sulphides are a final crystallisation stage (4), before decreased hydrothermal activity, and the oxidising effect of seawater causes the replacement of $\mathrm{Cu}$-rich phases by $\mathrm{Cu}$-poor minerals (5). An absence of bornite and that flow is still occurring (i.e., hydrothermal venting) suggests that current activity at Loki's Castle is early in this regime, perhaps stage 2 .

Compositionally, the mineralogy of Loki's Castle shows some departure from the norm. Several authors $([7,13,16]$, and $[8,45]$ for Loki's Castle itself) report that anhydrite, pyrrhotite, and local bornite are present and typical for high temperature SMS deposits (even sites that are still active, e.g., the Rainbow field, MAR), although these phases are generally absent from Loki's Castle. The Logatchev-1 ore field on the MAR, as with material from this study, lacks abundant pyrrhotite [13], but this is a long-lived and reworked deposit, very different in nature to Loki's Castle. Deposits containing limited pyrrhotite should result in low Fe sphalerite [50], because sphalerite equilibrating with pyrite should only be able to contain a small amount of Fe (after [51]). High-Fe sphalerite (i.e., over 10\%) should require a significant quantity of pyrrhotite present to act as a buffer for sulphur activity, yet sphalerite from Loki's Castle contains over 15\% Fe (after EPMA analyses). Moreover, the relatively straightforward sulphide suite and low $\mathrm{Pb}+\mathrm{As}+\mathrm{Sb}$ content of Loki's Castle suggests a sediment-starved system $[7,16]$, but the relatively low $\mathrm{Cu}$ grades observed are more in line with sediment-hosted deposits, which is contradictory to the mineralogical evidence and thermal regime. Additionally, despite historical correlations between $\mathrm{Cu}$ and $\mathrm{Au}$ in VMS deposits, strong $\mathrm{Zn}-\mathrm{Au}$ correlations in surface samples from the TAG are reported [36]—neither relationship is observed at Loki's Castle. Essentially, mineralogical implications made about other SMS deposits are not entirely applicable to Loki's Castle, based on the sampled material.

\subsubsection{Grade of Mineralised Material from Loki's Castle}

With respect to grade, multiple samples from Loki's Castle have economically interesting implications. Au at the surface and on the flanks of the TAG is typically below $1 \mathrm{ppm}$ [36], and average Au content of volcanic-hosted and sediment-hosted MOR SMSs is 1.2 and 0.8 ppm respectively [7], which is lower than the majority of samples in this study. Au content of high temperature chimney material is consistent with that of massive sulphides from the interior of the mounds and the underlying stockwork zones [7] which suggests the Au grades measured in this study could be continuous throughout the site. Similarly, $\mathrm{Zn}$ grades are good, Ag comparable, and $\mathrm{Cu}$ low when compared to other SMS deposits [7,12,16,52]; for example, the TAG has a central volume grading under $0.01 \%$ $\mathrm{Zn}$, but over $2 \% \mathrm{Cu}$ [36]. Land-based mafic-hosted VMS deposits have typical $\mathrm{Cu}, \mathrm{Zn}, \mathrm{Au}$, and $\mathrm{Ag}$ grades of $2 \%, 1.9 \%, 2.5 \mathrm{ppm}$ and $25 \mathrm{ppm}$, respectively [6], which are comparable with the values found in this study. That $\mathrm{Cu}$ in Loki's Castle is hosted principally by isocubanite may explain the lower $\mathrm{Cu}$ grades, compared to chalcopyrite-dominated deposits. Au- and Ag-bearing phases have not yet been observed at Loki's Castle, but literature reports that Au and Ag are usually present as native metals in SMS deposits. Native Au may occur in pores of isocubanite and chalcopyrite aggregates [12] in siliceous minerals adjacent to sphalerite and chalcopyrite, or as intergrowths with native arsenic [13]. Ag may occur natively in dendritic and zoned sphalerite [12], and may occur with $\mathrm{Au}$ in aragonite [13]. Localised enrichment of $\mathrm{Au}$ (over $40 \mathrm{ppm}$ ) is a possible consequence of remobilisation and reconcentration/hydrothermal reworking [7]; that these grades have not been observed could mean that the mineralisation at the Loki's Castle is primary, which corroborates the suggested immaturity of the current $\mathrm{Cu}-\mathrm{Fe}-\mathrm{S}$ system. 


\subsubsection{Considerations for Possible Exploration Strategies}

It is common knowledge that VMS deposits occur in clusters or within districts (e.g., [6]), and evidence is in place for additional, promising mineralised sites along the AMOR [26]. Despite studies suggesting that ultraslow spreading ridges should have a significantly reduced density of hydrothermal plumes due to a reduced magma budget (e.g., [53]), discoveries such as Loki's Castle and the TAG demonstrate that fast spreading ridges are not exclusively favourable for sites of mineralisation, and that exploration targets must be diversified. That $\mathrm{Fe}$ and $\mathrm{Cu}$ have good correlation could be exploited in exploration, especially as it appears that different sulphide phases are not mutually exclusive. If extensive sulphide mineralisation occurs, then all sulphide types are present, which means that pyrite could be an indicator for $\mathrm{Cu}$ and $\mathrm{Zn}$ mineralisation. Underwater hyperspectral imaging (UHI) has been demonstrated to have applications in the identification of SMS deposits based on mineralogy [54]; locating significant amounts of pyrite locates significant amounts of $\mathrm{Cu}$ and $\mathrm{Zn}$ sulphides by extension. Further, deleterious elements measured in the Loki's Castle material are promising for avoiding penalties-fines should be paid for every 1000 ppm As [55], with Japan and China having an import limit of 2000 and 5000 ppm As on base metal concentrates, respectively [56].

\subsection{Characterisation of Mineralised Material}

The second purpose of this study was to appraise the suitability of characterisation methods that are utilised during the mineralogical investigation, using Loki's Castle as a case study, with the view of informing downstream mineral processing techniques when combined with compositional details. Necessary outcomes were the definition of the best procedures for determining both the mineralogy and texture, which subsequently would help to determine the best extraction approach.

\subsubsection{Methods of Characterisation}

Reflected light microscopy, whilst somewhat undervalued, proved to be a useful technique in determining which minerals were present in mineralised material, the ranges of grain sizes, and textures/mineral associations. With ancillary work from XRD to confirm petrography, EPMA for mineralogical compositions and micron-scale texture mapping, and ICP-ES/MS and fire assay to determine grade, sulphide-bearing material, was characterised in detail. XRF was not pursued due to difficulties encountered with fluxing sulphides in platinum crucibles. QEMSCAN generated large scale textural maps, had good control over major and minor element chemistries, and allowed a series of mineralogical observations.

\subsubsection{Electron Beam Techniques in the Characterisation of Sulphide-bearing Material}

In addition to spatially resolved compositional maps, QEMSCAN provides phase association data. Pyrite/marcasite occurring mostly with silica is likely due to the gangue enveloping the sulphide phases, with pyrite/marcasite being the dominant phase. That isocubanite occurs overwhelmingly with chalcopyrite, but not the inverse, is because the isocubanite-dominated grains ubiquitously display chalcopyrite-bearing rims, which effectively isolate the chalcopyrite inclusion-containing isocubanite from other minerals. That chalcopyrite is reported to occur with pyrite/marcasite is an important processing consideration with respect to flotation. However, the quantitative validity of the QEMSCAN data pertaining to this should be questioned, as it is possible that sample preparation has caused QEMSCAN to misestimate the amount of pyrite/marcasite present in the sample. Large barite-shaped laths identified by QEMSCAN as pyrite/marcasite (Figure 7a) appear to be dominated by gangue/voids under reflected light, and these display a variable but typically low backscattered electron (BSE) response. The barite laths were probably coated by Fe-sulphides and likely plucked out during polishing, which exposed and therefore over-represented the Fe-sulphide phases/under-represented barite. This illustrates the necessity for quality sample preparation and verification by other technologies. Additionally, the identification of chalcocite/covellite should be 
considered carefully, as those grains identified as such by QEMSCAN do not correlate with reflected light petrography. Reported quantities of pyrite may be further distorted by the reporting of pyrite rims around $\mathrm{Cu}$-sulphide grains, which was not definitively observed in reflected light. Similarly, quantities of chalcopyrite and isocubanite are likely skewed by signals from intact chalcopyrite lamellae overriding poorly polished degraded isocubanite in some grain rims, and from chalcopyrite lamellae in isocubanite occurring at a scale smaller than EDS resolution (Figure $7 \mathrm{~b}-\mathrm{e}$ ).

Differences in QEMSCAN-derived composition (Table 2) must not be ascribed only to the improved resolution, because the $1 \mu \mathrm{m}$ pixel size region was targeted, specifically as it contained a higher proportion of sulphide mineralisation, and is a much smaller domain $\left(9 \mathrm{~mm}^{2}\right)$ within a larger area $\left(560 \mathrm{~mm}^{2}\right)$. Additionally, failure to detect microtextures distorts the weight $\%$, volume $\%$, grain size, and mineral association data. With this in mind, knowing the expected texture scale is important to maximise the accuracy of the data by applying the correct beam conditions for all beam techniques. The results suggest that a $1 \mu \mathrm{m}$ step size is superior to $10 \mu \mathrm{m}$ (at least for QEMSCAN), but realistically, this is still not high enough for characterisation of the $\mathrm{Cu}$-sulphide phases in this case. At the microscales present in these samples, the interaction volume of the beam is critical. BSE and generated X-rays have interaction volumes in the order of $1 \mu \mathrm{m}$ and $5 \mu \mathrm{m}$, respectively (depending on beam angle and energy [57]), which, considering the scale of observed microtextures, it is not entirely appropriate for the complete characterisation of Loki's Castle sulphides. Indeed, mapping textures finer than $2 \mu \mathrm{m}$ also proved challenging with EPMA.

\subsubsection{Implications for Mineral Processing}

Ultimately, the methods utilised in this detailed mineralogical investigation provided the information necessary to steer downstream mineral processing experiments [58,59]. It was determined that these sulphide phases are extremely fine grained, with an average grain size of 9, 5, 4, and $11 \mu \mathrm{m}$ for pyrite/marcasite, chalcopyrite, isocubanite, and sphalerite respectively, sub-1.5 $\mu \mathrm{m}$ minimum grain sizes for all minerals (after QEMSCAN analysis at $1 \mu \mathrm{m}$ pixel spacing), and ubiquitous sub-micron intergrowths of $\mathrm{Cu}-\mathrm{Fe}-\mathrm{S}$ phases. This meant that conventional froth flotation could be more or less excluded as an efficient way of concentrating these metals, as standard grinding could not liberate the different sulphide phases sufficiently to ensure their subsequent separation by flotation. Leaching proved to be a more appropriate technique, with $\mathrm{Cu}, \mathrm{Zn}$, and Ag being successfully extracted from mineralised material from the Loki's Castle. From the perspective of the extractive and processing industries, the characterisation methods discussed can be directly applied to determining approaches to processing.

\section{Conclusions}

1. Sulphide-bearing material from a hydrothermal vent site on the AMOR is characterised in detail for the first time; sulphide mineralisation consists of chalcopyrite, isocubanite, and sphalerite, with pyrite, marcasite, and lesser galena and pyrrhotite, whilst Au- and Ag-bearing phases remain undefined.

2. Several instances of $\mathrm{Cu}, \mathrm{Zn}, \mathrm{Au}$, and $\mathrm{Ag}$ grades at the Loki's Castle hydrothermal vent system are favourable compared to the average grades of other SMS deposits and to mafic-hosted VMS deposits. Further investigation of in situ samples (e.g., drill cores) is a necessity before any economic conclusions can be drawn.

3. Fundamental microscopy is an effective methodology to identify minerals and mineral textures in mineralised vent material. QEMSCAN can be used to effectively, graphically, spatially, and statistically determine mineral textures at a scale above $10 \mu \mathrm{m}$, but even at a $1 \mu \mathrm{m}$ pixel spacing, it fails to define some micron-scale features, which requires EPMA. QEMSCAN can be used to efficiently generate grain size and mineral association data, as well as compositional data, and it is likely to be a powerful tool in assessing the effectiveness of SMS mineral processing. 
Author Contributions: Conceptualization, B.S. and K.A.; Methodology, B.S.; Formal Analysis, B.S.; Investigation, B.S., K.D., G.K.R. and K.A.; Writing-Original Draft Preparation, B.S.; Writing-Review \& Editing, B.S., K.D., G.K.R. and K.A.; Visualization, B.S.; Funding Acquisition, K.A.

Funding: This work was funded by the Research Council of Norway (Norges Forskningsråd, NFR) Project No. 247626/O30.

Acknowledgments: The authors gratefully acknowledge Morten Peder Raanes, NTNU for his technical assistance with the EPMA, and Laurentius Tijhuis, NTNU for his technical assistance with the XRD.

Conflicts of Interest: The authors declare no conflict of interest.

\section{Appendix A}

Table A1. Elemental detection limits (ppm) for each analysis point for EPMA analyses (Table 4).

\begin{tabular}{ccccccccccccc}
\hline Point & $\mathbf{A s}$ & $\mathbf{S}$ & $\mathbf{M n}$ & $\mathbf{P b}$ & $\mathbf{F e}$ & $\mathbf{B i}$ & $\mathbf{C o}$ & $\mathbf{C d}$ & $\mathbf{N i}$ & $\mathbf{S b}$ & $\mathbf{C u}$ & $\mathbf{Z n}$ \\
\hline 1 ccp & 122.0 & 0.6 & 216.2 & 441.0 & 0.5 & 100.0 & 34.6 & 87.5 & 100.0 & 151.3 & 0.5 & 12.9 \\
$2 \mathrm{ccp}$ & 100.0 & 0.6 & 99.1 & 344.6 & 0.5 & 100.0 & 34.8 & 482.5 & 100.0 & 100.0 & 0.5 & 12.6 \\
$3 \mathrm{ccp}$ & 100.0 & 0.6 & 319.3 & 100.0 & 0.5 & 100.0 & 22.6 & 129.3 & 100.0 & 192.5 & 0.5 & 11.5 \\
$4 \mathrm{ccp}$ & 526.6 & 0.6 & 68.4 & 333.5 & 0.5 & 100.0 & 20.3 & 223.0 & 100.0 & 61.8 & 0.5 & 8.9 \\
$5 \mathrm{spl}$ & 100.0 & 0.6 & 3.7 & 100.0 & 0.7 & 100.0 & 44.2 & 16.7 & 100.0 & 100.0 & 17.2 & 0.5 \\
$6 \mathrm{spl}$ & 100.0 & 0.6 & 3.8 & 163.0 & 0.7 & 100.0 & 41.0 & 19.5 & 82.2 & 100.0 & 14.7 & 0.5 \\
$7 \mathrm{spl}$ & 100.0 & 0.6 & 3.1 & 100.0 & 0.6 & 100.0 & 79.2 & 19.7 & 105.2 & 171.8 & 2.1 & 0.5 \\
$8 \mathrm{spl}$ & 100.0 & 0.6 & 2.9 & 79.7 & 0.6 & 100.0 & 74.0 & 26.4 & 68.2 & 100.0 & 1.9 & 0.5 \\
$9 \mathrm{spl}$ & 100.0 & 0.6 & 3.0 & 56.8 & 0.7 & 100.0 & 103.8 & 31.7 & 112.8 & 100.0 & 5.3 & 0.5 \\
$10 \mathrm{spl}$ & 100.0 & 0.6 & 2.8 & 100.0 & 0.6 & 100.0 & 230.4 & 26.9 & 100.0 & 108.7 & 3.0 & 0.5 \\
$11 \mathrm{gn}$ & 100.0 & 0.9 & 100.0 & 0.8 & 6.4 & 100.0 & 100.0 & 26.3 & 113.8 & 100.0 & 9.0 & 33.5 \\
$12 \mathrm{gn}$ & 100.0 & 0.9 & 100.0 & 0.8 & 9.9 & 100.0 & 100.0 & 20.6 & 100.0 & 75.9 & 20.5 & 83.4 \\
13 iso & 388.7 & 0.6 & 16.9 & 406.9 & 0.4 & 100.0 & 23.1 & 160.8 & 100.0 & 209.2 & 0.7 & 6.7 \\
14 iso & 100.0 & 0.6 & 18.6 & 58.2 & 0.4 & 100.0 & 29.8 & 100.0 & 45.2 & 54.9 & 0.7 & 3.1 \\
\hline
\end{tabular}

\section{References}

1. Singer, D.A. Future copper resources. Ore Geol. Rev. 2017, 86, 271-279. [CrossRef]

2. European Comission-Critical Raw Materials. Available online: http://ec.europa.eu/growth/sectors/rawmaterials/specific-interest/critical_en (accessed on 18 July 2018).

3. German, C.R.; Petersen, S.; Hannington, M.D. Hydrothermal exploration of mid-ocean ridges: Where might the largest sulfide deposits be forming? Chem. Geol. 2016, 420, 114-126. [CrossRef]

4. Hannington, M.; Jamieson, J.; Monecke, T.; Petersen, S.; Beaulieu, S. The abundance of seafloor massive sulfide deposits. Geology 2011, 39, 1155-1158. [CrossRef]

5. White, M.; Manocchio, A.; Sant, T.; Johnston, M.; Lowe, J.; Minerals, N. Resource drilling of the solwara 1 seafloor massive sulfide (SMS) deposit. In Proceedings of the Offshore Technology Conference, Houston, TX, USA, 2-5 May 2011.

6. Galley, A.G.; Hannington, M.D.; Jonasson, I.R. Volcanogenic massive sulfide deposits. In Mineral Deposits of Canada: A Synthesis of Major Deposit-Types, District Metallogeny, the Evolution of Geological Provinces, and Exploration Methods; Goodfellow, W.D., Ed.; Geological Association of Canada: St. John's, NL, Canada, 2007; pp. 141-161.

7. Herzig, P.M.; Hannington, M.D. Polymetallic massive sulfides at the modern seafloor a review. Ore Geol. Rev. 1995, 10, 95-115. [CrossRef]

8. Pedersen, R.B.; Rapp, H.T.; Thorseth, I.H.; Lilley, M.D.; Barriga, F.J.A.S.; Baumberger, T.; Flesland, K.; Fonseca, R.; Früh-Green, G.L.; Jorgensen, S.L. Discovery of a black smoker vent field and vent fauna at the arctic mid-ocean ridge. Nat. Commun. 2010, 1, 126. [CrossRef] [PubMed]

9. Humphris, S.E.; Herzig, P.M.; Miller, D.J.; Alt, J.C.; Becker, K.; Brown, D.; Brügmann, G.; Chiba, H.; Fouquet, Y.; Gemmell, J.B.; et al. The internal structure of an active sea-floor massive sulphide deposit. Nature 1995, 377, 713-716. [CrossRef] 
10. Monecke, T.; Petersen, S.; Hannington, M.D.; Grant, H.; Samson, I. The minor element endowment of modern sea-floor massive sulfide deposits and comparison with deposits hosted in ancient volcanic successions. In Rare Earth and Critical Elements in Ore Deposits; Verplanck, P.L., Hitzman, M.W., Eds.; Society of Economic Geologists: Knoxville, TN, USA, 2016; Volume 18, pp. 245-306.

11. Eickmann, B.; Thorseth, I.H.; Peters, M.; Strauss, H.; Brocker, M.; Pedersen, R.B. Barite in hydrothermal environments as a recorder of subseafloor processes: A multiple-isotope study from the loki's castle vent field. Geobiology 2014, 12, 308-321. [CrossRef] [PubMed]

12. Firstova, A.; Stepanova, T.; Cherkashov, G.; Goncharov, A.; Babaeva, S. Composition and formation of gabbro-peridotite hosted seafloor massive sulfide deposits from the ashadze-1 hydrothermal field, mid-atlantic ridge. Minerals 2016, 6, 19. [CrossRef]

13. Mozgova, N.N.; Borodaev, Y.S.; Gablina, I.F.; Cherkashev, G.A.; Stepanova, T.V. Mineral assemblages as indicators of the maturity of oceanic hydrothermal sulfide mounds. Lithol. Miner. Resour. 2005, 40, $293-319$. [CrossRef]

14. Rona, P.A.; Petersen, S.; Becker, K.; Von Herzen, R.P.; Hannington, M.D.; Herzig, P.M.; Naka, J.; Lalou, C.; Thompson, G. Heat flow and mineralogy of TAG relict high-temperature hydrothermal zones: Mid-Atlantic ridge $26^{\circ} \mathrm{N}, 45^{\circ} \mathrm{W}$. Geophys. Res. Lett. 1996, 23, 3507-3510. [CrossRef]

15. Brett, R.; Evans, H.T.; Gibson, E.K.; Hedenquist, J.W.; Wandless, M.V.; Sommer, M.A. Mineralogical studies of sulfide samples and volatile concentrations of basalt glasses from the southern Juan de Fuca ridge. J. Geophys. Res. Solid Earth 1987, 92, 11373-11379. [CrossRef]

16. Krasnov, S.; Stepanova, T.; Stepanov, M. Chemical composition and formation of a massive sulfide deposit, middle valley, northern Juan de Fuca ridge (site 856). In Proceedings of the Ocean Drilling Program, 139 Scientific Results; Texas A\&M University: College Station, TX, USA, 1994.

17. Conte, A.M.; Caramanna, G. Preliminary characterisation of a shallow water hydrothermal sulphide deposit recovered by scientific divers (Aeolian Islands, southern Tyrrhenian Sea). Underw. Technol. 2010, 29, 109-115. [CrossRef]

18. Iizasa, K.; Yuasa, M.; Yokota, S. Mineralogy and geochemistry of volcanogenic sulfides from the Myojinsho submarine caldera, the Sshichito-Iwojima ridge, Izu-ogasawara arc, northwestern Pacific. Mar. Geol. 1992, 108, 39-58. [CrossRef]

19. Missack, E.; Stoffers, P.; El Goresy, A. Mineralogy, parageneses, and phase relations of copper-iron sulfides in the Atlantis II Deep, Red Sea. Miner. Deposita 1989, 24, 82-91. [CrossRef]

20. Schlindwein, V. Ultraslow spreading processes along the Arctic mid-ocean ridge system. In Proceedings of the EPIC3EGU General Assembly, Vienna, Austria, 7-11 April 2013.

21. Cruz, M.I.; Dias, A.S.; Relvas, J.M.R.S.; Carvalho, C.; Fonseca, R.; Pedersen, R.B.; Barriga, F.J.A.S. Geochemistry of the Artic Loki's Castle hydrothermal vent products. In Proceedings of the Goldschmidt Conference, Prague, Czech Republic, 14-19 August 2011.

22. Pedersen, R.B.; Thorseth, I.H.; Nygård, T.E.; Lilley, M.D.; Kelley, D.S. Hydrothermal activity at the Arctic mid-ocean ridges. Divers. Hydrothermal Syst. Slow Spreading Ocean Ridges 2013, 188, 67-89.

23. Kelley, D.S.; Karson, J.A.; Blackman, D.K.; Früh-Green, G.L.; Butterfield, D.A.; Lilley, M.D.; Olson, E.J.; Schrenk, M.O.; Roe, K.K.; Lebon, G.T.; et al. An off-axis hydrothermal vent field near the mid-Atlantic ridge at $30^{\circ}$ N. Nature 2001, 412, 145-149. [CrossRef] [PubMed]

24. Boschi, C.; Früh-Green, G.L.; Delacour, A.; Karson, J.A.; Kelley, D.S. Mass transfer and fluid flow during detachment faulting and development of an oceanic core complex, Atlantis Massif (MAR $30^{\circ} \mathrm{N}$ ). Geochem. Geophys. Geosyst. 2006, 7. [CrossRef]

25. McCaig, A.M.; Cliff, R.A.; Escartin, J.; Fallick, A.E.; MacLeod, C.J. Oceanic detachment faults focus very large volumes of black smoker fluids. Geology 2007, 35, 935. [CrossRef]

26. Juliani, C.; Ellefmo, S.L. Probabilistic estimates of permissive areas for undiscovered seafloor massive sulfide deposits on an Arctic mid-ocean ridge. Ore Geol. Rev. 2018, 95, 917-930. [CrossRef]

27. Geomapapp. Available online: http://www.geomapapp.org (accessed on 18 July 2018).

28. Ryan, W.B.F.; Carbotte, S.M.; Coplan, J.O.; O’Hara, S.; Melkonian, A.; Arko, R.; Weissel, R.A.; Ferrini, V.; Goodwillie, A.; Nitsche, F.; et al. Global multi-resolution topography synthesis. Geochem. Geophys. Geosyst. 2009, 10. [CrossRef] 
29. Ludvigsen, M.; Aasly, K.; Ellefmo, S.L.; Hilário, A.; Ramirez-Llodra, E.; Søreide, F.X.; Falcon-Suarez, I.; Juliani, C.J.; Kieswetter, A.; Lim, A.; et al. Marmine Cruise Report-Arctic Mid-Ocean Ridge 15.08.2016-05.09.2016; NTNU: Trondheim, Norway, 2016.

30. Bruvoll, V.; Breivik, A.J.; Mjelde, R.; Pedersen, R.B. Burial of the Mohn-Knipovich seafloor spreading ridge by the Bear Island fan: Time constraints on tectonic evolution from seismic stratigraphy. Tectonics 2009, 28. [CrossRef]

31. Baumberger, T.; Früh-Green, G.L.; Thorseth, I.H.; Lilley, M.D.; Hamelin, C.; Bernasconi, S.M.; Okland, I.E.; Pedersen, R.B. Fluid composition of the sediment-influenced Loki's Castle vent field at the ultra-slow spreading Arctic mid-ocean ridge. Geochim. Cosmochim. Acta 2016, 187, 156-178. [CrossRef]

32. Charlou, J.L.; Donval, J.P.; Fouquet, Y.; Jean-Baptiste, P.; Holm, N. Geochemistry of high $\mathrm{H}_{2}$ and $\mathrm{CH}_{4}$ vent fluids issuing from ultramafic rocks at the Rainbow hydrothermal field ( $\left.36^{\circ} 14^{\prime} \mathrm{N}, \mathrm{MAR}\right)$. Chem. Geol. 2002, 191, 345-359. [CrossRef]

33. Proskurowski, G.; Lilley, M.D.; Kelley, D.S.; Olson, E.J. Low temperature volatile production at the lost city hydrothermal field, evidence from a hydrogen stable isotope geothermometer. Chem. Geol. 2006, 229, 331-343. [CrossRef]

34. Fontaine, F.J.; Wilcock, W.S.D.; Foustoukos, D.E.; Butterfield, D.A. A Si-Cl geothermobarometer for the reaction zone of high-temperature, basaltic-hosted mid-ocean ridge hydrothermal systems. Geochem. Geophys. Geosyst. 2009, 10. [CrossRef]

35. Klingelhofer, F.; Geli, L.; Matias, L.; Steinsland, N.; Mohr, J. Crustal structure of a super-slow spreading centre: A seismic refraction study of Mohns Ridge, $72^{\circ}$ N. Geophys. J. Int. 2000, 141, 509-526. [CrossRef]

36. Hannington, M.D.; Galley, A.G.; Herzig, P.M.; Petersen, S. Comparison of the TAG mound and stockwork complex with Cyprus-type massive sulphide deposits. Proc. Ocean Drill. Prog. Sci. Results 1998, 158, 389-415.

37. Gottlieb, P.; Wilkie, G.; Sutherland, D.; Ho-Tun, E.; Suthers, S.; Perera, K.; Jenkins, B.; Spencer, S.; Butcher, A.; Rayner, J. Using quantitative electron microscopy for process mineralogy applications. JOM 2000, 52, $24-25$. [CrossRef]

38. Pirrie, D.; Butcher, A.R.; Power, M.R.; Gottlieb, P.; Miller, G.L. Rapid quantitative mineral and phase analysis using automated scanning electron microscopy (QEMSCAN); potential applications in forensic geoscience. In Forensic Geoscience, Principles, Techniques and Applications; Pye, K., Croft, D.J., Eds.; Geological Society Special Publication: London, UK, 2004; Volume 232, pp. 123-136.

39. Pirrie, D.; Rollinson, G.K. Unlocking the applications of automated mineral analysis. Geol. Today 2011, 27, 226-235. [CrossRef]

40. Andersen, J.C.Ø.; Rollinson, G.K.; Snook, B.; Herrington, R.; Fairhurst, R.J. Use of QEMSCAN ${ }^{\circledR}$ for the characterization of Ni-rich and Ni-poor goethite in laterite ores. Miner. Eng. 2009, 22, 1119-1129. [CrossRef]

41. Rollinson, G.K.; Andersen, J.C.Ø.; Stickland, R.J.; Boni, M.; Fairhurst, R. Characterisation of non-sulphide zinc deposits using QEMSCAN ${ }^{\circledR}$. Miner. Eng. 2011, 24, 778-787. [CrossRef]

42. Barton, P.B., Jr.; Bethke, P.M. Chalcopyrite disease in sphalerite: Pathology and epidemiology. Am. Miner. 1987, 72, 451-467.

43. Whitney, D.L.; Evans, B.W. Abbreviations for names of rock-forming minerals. Am. Miner. 2010, 95, $185-187$. [CrossRef]

44. McDonough, W.F.; Sun, S.-S. The composition of the earth. Chem. Geol. 1995, 120, 223-253. [CrossRef]

45. Cruz, M.I. Mineralogy and geochemistry of contrasting hydrothermal systems on the Arctic mid-ocean ridge (AMOR): The Jan Mayen and Loki's Castle vent fields. Ph.D. Thesis, Universidade de Lisboa, Lisboa, Portugal, 2016.

46. Yıldırım, N.; Dönmez, C.; Kang, J.; Lee, I.; Pirajno, F.; Yıldırım, E.; Günay, K.; Seo, J.H.; Farquhar, J.; Chang, S.W. A magnetite-rich Cyprus-type VMS deposit in Ortaklar: A unique VMS style in the Tethyan metallogenic belt, Gaziantep, Turkey. Ore Geol. Rev. 2016, 79, 425-442. [CrossRef]

47. Steeves, N.J.; Hannington, M.D.; Gemmell, J.B.; Green, D.; McVeigh, G. The glacier creek Cu-Zn VMS deposit, southeast Alaska: An addition to the Alexander Triassic metallogenic belt. Econ. Geol. 2016, 111, 151-178. [CrossRef]

48. Gromet, L.P.; Haskin, L.A.; Korotev, R.L.; Dymek, R.F. The "North American shale composite": Its compilation, major and trace element characteristics. Geochim. Cosmochim. Acta 1984, 48, 2469-2482. [CrossRef]

49. Yund, R.A.; Kullerud, G. Thermal stability of assemblages in the Cu-Fe-S system. J. Petrol. 1966, 7, 454-488. [CrossRef] 
50. Craig, J.R.; Ljokjell, P.; Vokes, F.M. Sphalerite compositional variations in sulfide ores of the Norwegian Caledonides. Econ. Geol. 1984, 79, 1727-1735. [CrossRef]

51. Barton, P.B., Jr.; Skinner, B.J. Sulfide mineral stabilities. In Geochemistry of Hydrothermal ore Deposits; Barnes, H.L., Ed.; Wiley-Interscience: New York, NY, USA, 1979; pp. $278-403$.

52. Fallon, E.K.; Petersen, S.; Brooker, R.A.; Scott, T.B. Oxidative dissolution of hydrothermal mixed-sulphide ore: An assessment of current knowledge in relation to seafloor massive sulphide mining. Ore Geol. Rev. 2017, 86, 309-337. [CrossRef]

53. Baker, E.T.; German, C.R. On the global distribution of hydrothermal vent fields. In Mid-Ocean Ridges; German, C., Lin, J., Parson, L., Eds.; American Geophysical Union: Washington, DC, USA, 2013; Volume 148.55 .

54. Dumke, I.; Ludvigsen, M.; Ellefmo, S.L.; Søreide, F.; Johnsen, G.; Murton, B.J. Underwater hyperspectral imaging using a stationary platform in the Trans-Atlantic Geotraverse hydrothermal field. IEEE Trans. Geosci. Remote Sens. 2017, Submitted.

55. OECD—The Platform for Cooperation on Tax Discussion Draft: Addressing the Information Gaps on Prices of Minerals Sold in an Intermediate Form. Available online: https:/ /www.oecd.org/ctp/discussion-draftaddressing-the-information-gaps-on-prices-of-minerals-sold-in-an-intermediate-form.pdf (accessed on 20 July 2018).

56. Fountain, C. The whys and wherefores of penalty elements in copper concentrates. MetPlant 2013, 5, 502-518.

57. Goldstein, J.I.; Newbury, D.E.; Michael, J.R.; Ritchie, N.W.M.; Scott, J.H.J.; Joy, D.C. Scanning Electron Microscopy and $x$-ray Microanalysis, 3rd ed.; Springer: New York, NY, USA, 2003.

58. Kowalczuk, P.B.; Snook, B.; Kleiv, R.A.; Aasly, K. Efficient extraction of copper and zinc from seafloor massive sulphide rock samples from the Loki's Castle area at the Arctic mid-ocean ridge. Miner. Eng. 2018, 115, 106-116. [CrossRef]

59. Kowalczuk, P.; Manaig, D.; Drivenes, K.; Snook, B.; Aasly, K.; Kleiv, R. Galvanic leaching of seafloor massive sulphides using $\mathrm{MnO}_{2}$ in $\mathrm{H}_{2} \mathrm{SO}_{4}-\mathrm{NaCl}$ media. Minerals 2018, 8, 235. [CrossRef]

(C) 2018 by the authors. Licensee MDPI, Basel, Switzerland. This article is an open access article distributed under the terms and conditions of the Creative Commons Attribution (CC BY) license (http:/ / creativecommons.org/licenses/by/4.0/). 